\title{
Mechanochemical Preparation of Hydantoins from Amino Esters: Application to the Synthesis of the Antiepileptic Drug Phenytoin
}

\author{
Laure Konnert, ${ }^{\dagger}$ Benjamin Reneaud, ${ }^{\dagger}$ Renata Marcia de Figueiredo, ${ }^{\ddagger}$ Jean-Marc Campagne, ${ }^{\ddagger}$ \\ Frédéric Lamaty, ${ }^{\dagger}$ Jean Martinez, ${ }^{\dagger}$ and Evelina Colacino ${ }^{*},^{\dagger}$ \\ †Université Montpellier II, Institut des Biomolécules Max Mousseron UMR 5247 CNRS - Universités Montpellier I \& II - ENSCM, \\ Place E. Bataillon, cc 1703, 34095 Montpellier, France \\ ${ }^{\ddagger}$ Institut Charles Gerhardt Montpellier (ICGM), UMR 5253 CNRS-UM2-UM1-ENSCM, Ecole Nationale Supérieure de Chimie, 8 \\ Rue de l'Ecole Normale, 34296 Montpellier Cedex 5, France
}

ABSTRACT: The eco-friendly preparation of 5- and 5,5disubstituted hydantoins from various amino ester hydrochlorides and potassium cyanate in a planetary ball-mill is described. The one-pot/two-step protocol consisted in the formation of ureido ester intermediates, followed by a base-catalyzed cyclization to hydantoins. This easy-handling mechanochemical methodology was applied to a large variety of $\alpha$ - and $\beta$-amino esters, in smooth conditions, leading to hydantoins in good yields and with no need of purification steps. As an example, the methodology was applied to the "green" synthesis of the antiepileptic drug Phenytoin, with no use of any harmful organic solvent.

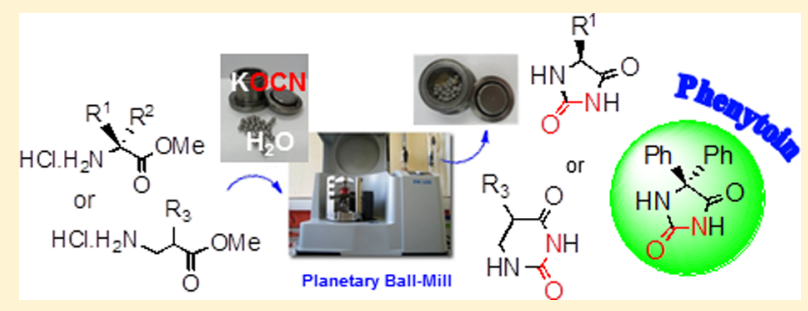

\section{INTRODUCTION}

2,4-Imidazolidinediones, also known as hydantoins, are a class of well-known molecules that have demonstrated a wide therapeutic interest, ${ }^{1}$ including antiepileptic, ${ }^{2}$ anticonvulsant, ${ }^{3}$ antiandrogenic, ${ }^{4}$ antidiabetic ${ }^{5}$ or antifungal activities. ${ }^{6}$ From the synthetic point of view, hydantoins are precursors of choice of $\alpha$-amino acids, ${ }^{7}$ or provide access to optically active polymers ${ }^{8}$ or metal complexes. ${ }^{9,10}$ A particular hydantoin, 1,3-dibromo5,5'-dimethylhydantoin (DBDMH), is used for bromination reactions $^{11,12}$ and acts as a catalyst in a number of organic transformations. ${ }^{13-15}$ There are three main pathways to access 1,3-unsubstituted hydantoins, ${ }^{1,7,16}$ the choice of which depends not only on the synthetic easiness to access the precursors, but also on the final target that includes 5-substituted or 5,5disubstituted hydantoins (Scheme 1).

Under Bucherer-Bergs conditions ${ }^{17,18}$ involving a carbonyl compound, toxic potassium cyanide and ammonium carbonate, mainly 5-substituted hydantoins were obtained. A few examples exploited this approach to access 5,5-disubstituted derivatives, ${ }^{8}$ and very recently a variant methodology, starting from a methylene aziridine instead of a carbonyl compound, was also reported for the synthesis of this class of compounds. ${ }^{19}$ Reactions were mainly performed in solution under reflux or microwaves $^{20}(\mathrm{MW})$. Neat conditions ${ }^{21}$ were also reported, involving $\mathrm{Fe}_{3} \mathrm{O}_{4}$ nanoparticles as catalyst. ${ }^{22}$ The second major pathway to obtain 1,3-unsubstituted hydantoins is the reaction of cyanate salts with either amino acids ${ }^{6}$ or their ester, ${ }^{7,23}$ amide or nitrile ${ }^{24}$ derivatives, known as the Read synthesis. The corresponding ureido derivative was cyclized under acidic conditions, although the base catalyzed-cyclization has also been reported. ${ }^{25}$ This reaction has been notably used for the preparation of spirohydantoins. ${ }^{26}$ Trimethylsilyl-isocyanate (TMS-NCO) and chlorosulfonyl-isocyanate are alternatives to cyanate salts for the preparation of 1,3-unsubstituted hydantoins. ${ }^{27,28}$ Recently, our group has described the solidphase synthesis of 5-substituted hydantoins under microwaveirradiation from supported amino acids and isocyanates. ${ }^{29}$ The condensation of benzil and urea in excess according to Biltz reaction ${ }^{7,30,31}$ remains the main pathway to the obtention of 5,5-disubstituted hydantoins and was historically used for the synthesis of the antiepileptic drug phenytoin.,31 Several improvements were described using enabling technologies such as ultrasonication, ${ }^{32,33}$ heating via microwave irradiation (in solution or neat ${ }^{34-37}$ ), in polar solvents [water, ${ }^{2}$ poly(ethylene glycol) ${ }^{38}$ or $\left.\mathrm{DMSO}^{34}\right]$ or grinding the reactants (with mortar and pestle). ${ }^{39}$ In view of the REACH (Registration, Evaluation, Authorisation and Restriction of Chemicals) legislation, ${ }^{40}$ regulating chemical substances and directed to both the protection of the human health and the environment from the risks of potentially toxic chemicals, the use of certain chemicals will be phased out, affecting industries throughout the world. Thus, the use of possible alternative substances and/ or technologies, including present and future research and development processes, will enhance innovation and competitiveness. In this perspective, reduction or elimination of harmful chemicals includes the possibility to perform organic synthesis in the absence of solvents, in neat conditions ${ }^{41}$ or via mechanochemistry. ${ }^{42,43}$ Ball-milling technology has been, for the past decade, more and more used in the field of organic 
Scheme 1. Main Retrosynthetic Pathways to the Synthesis of 1,3-Unsubstituted Hydantoins

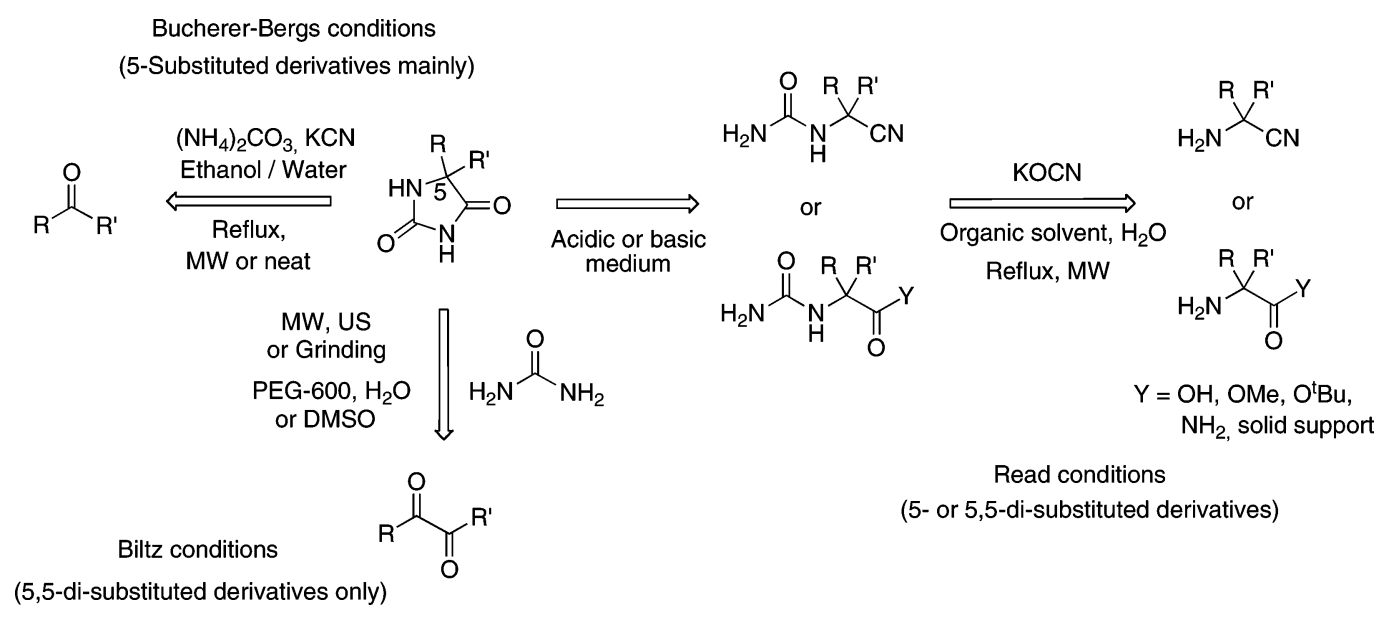

Table 1. Screening of the Conditions for the Synthesis of 5-Benzyl-hydantoin 2

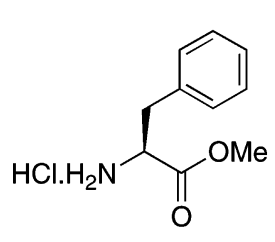

Vibrational or Planetary
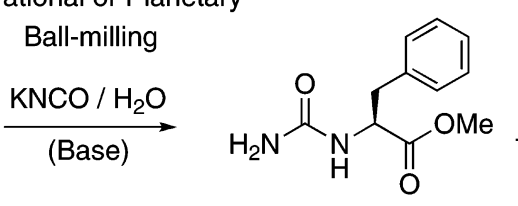<smiles>O=C1NC(=O)C(Cc2ccccc2)N1</smiles>

\begin{tabular}{|c|c|c|c|c|c|}
\hline \multirow[b]{2}{*}{ entry } & \multirow[b]{2}{*}{ base $^{a}$} & \multirow[b]{2}{*}{ 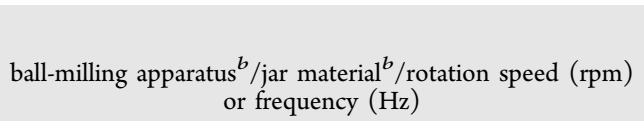 } & \multirow[b]{2}{*}{ time $(\mathrm{h})$} & \multicolumn{2}{|c|}{ conversion (HPLC \%) } \\
\hline & & & & 1 & 2 \\
\hline 1 & $\mathrm{~K}_{2} \mathrm{CO}_{3}$ & $\mathrm{VM} / \mathrm{SS} / 30 \mathrm{~Hz}$ & 2 & 0 & 0 \\
\hline 2 & $\mathrm{NaHCO}_{3}$ & $\mathrm{VM} / \mathrm{SS} / 30 \mathrm{~Hz}$ & 4 & 70 & 0 \\
\hline 3 & $\mathrm{NaHCO}_{3}$ & $\mathrm{PM} / \mathrm{SS} / 500 \mathrm{rpm}$ & 4 & 70 & 0 \\
\hline 4 & $\mathrm{NaHCO}_{3}$ & $\mathrm{PM} / \mathrm{SS} / 500 \mathrm{rpm}$ & $6^{c}$ & 90 & traces \\
\hline 5 & $\mathrm{NaHCO}_{3}$ & $\mathrm{PM} / \mathrm{WC} / 500 \mathrm{rpm}$ & $6^{c}$ & 84 & traces \\
\hline 6 & $\mathrm{~K}_{2} \mathrm{CO}_{3}$ & $\mathrm{PM} / \mathrm{SS} / 500 \mathrm{rpm}$ & $4^{c}$ & 0 & 0 \\
\hline 7 & $\mathrm{Et}_{3} \mathrm{~N}$ (excess) & $\mathrm{PM} / \mathrm{SS} / 500 \mathrm{rpm}$ & $4^{c}$ & 0 & 0 \\
\hline $8^{d, e}$ & $\mathrm{Et}_{3} \mathrm{~N} / \mathrm{H}_{2} \mathrm{O}$ & / & $24^{e}$ & 0 & 90 \\
\hline $9^{f}$ & $\mathrm{Et}_{3} \mathrm{~N} / \mathrm{H}_{2} \mathrm{O}$ & $\mathrm{PM} / \mathrm{SS} / 500 \mathrm{rpm}$ & $6^{c}$ & 37 & 21 \\
\hline \multirow[t]{2}{*}{$10^{g}$} & $\mathrm{NaHCO}_{3}$ (step 1) & $\mathrm{PM} / \mathrm{SS} / 300 \mathrm{rpm}$ & $3^{c}$ & 91 & n.d. ${ }^{h}$ \\
\hline & $\mathrm{Et}_{3} \mathrm{~N} / \mathrm{H}_{2} \mathrm{O}($ step 2$)$ & $\mathrm{PM} / \mathrm{SS} / 500 \mathrm{rpm}$ & $6^{c}$ & n.a. ${ }^{h}$ & 31 \\
\hline
\end{tabular}

$a_{2}$ equiv of base were used. ${ }^{b}$ Typical procedure: L-phenylalanine methyl ester hydrochloride ( 1 equiv), KNCO ( 1 equiv) and the base ( 2 equiv) were milled in a vibrational ball-mill (VM), $10 \mathrm{~mL}$ stainless steel (SS) jar, 2 stainless steel balls ( $5 \mathrm{~mm}$ diameter) at $30 \mathrm{~Hz}$ or in a planetary ball-mill (PM), $12 \mathrm{~mL}$ stainless steel or $50 \mathrm{~mL}$ tungsten carbide (WC) jar, 25 stainless steel balls (or 50 tungsten carbide balls, 5 mm diameter) at 500 (or $300 \mathrm{rpm}$ ) for the specified time. ${ }^{c}$ Cycled milling of 10 min cycles followed by 5 min of standby in between, with reverse rotation, for the specified time. ${ }^{d}$ The phenylalanyl-urea 1 was the starting material. ${ }^{e}$ The reaction was performed under stirring at room temperature. ${ }^{f}$ The reaction was carried out using Lphenylalanine methyl ester hydrochloride $(3.48 \mathrm{mmol}), \mathrm{Et}_{3} \mathrm{~N}(6.96 \mathrm{mmol})$ and $\mathrm{H}_{2} \mathrm{O}(200 \mu \mathrm{L}) .{ }^{g}$ Step 1: $\mathrm{NaHCO}_{3}(6.96 \mathrm{mmol}) ;$ Step 2: $\mathrm{Et}_{3} \mathrm{~N}(6.96$ $\mathrm{mmol})$ and $\mathrm{H}_{2} \mathrm{O}(1 \mathrm{~mL}) .{ }^{h}$.d. = not determined; n.a. = not attributed.

chemistry. ${ }^{44-46}$ The mechanosynthesis of heterocyclic compounds has been notably explored. ${ }^{47,48}$ However, as far as we know, no mechanochemical procedure for the preparation of hydantoins has ever been developed. In our ongoing work on organic mechanochemistry, ${ }^{49-56}$ investigation of a solvent-free methodology for the synthesis of hydantoins starting from amino ester derivatives in a ball-mill seemed promising. It is worth noting that the use of mechanochemistry for the synthesis of heterocycles from amino acid derivatives remains a quite unexplored field, with only one example describing the synthesis of $(R)$-thiazolidine from L-cysteine. ${ }^{57}$

Herein we describe a systematic investigation and a general method for the eco-friendly mechanochemical synthesis of 5substituted hydantoins from a large variety of amino acid methyl esters and potassium cyanate (Scheme 1). The ureido intermediate could be either isolated, or cyclized in the presence of base, to afford pure hydantoins in good to excellent yields without purification. The methodology was also applied to the synthesis of the 5,5-disubstituted antiepileptic drug, phenytoin. Compared to solution synthesis, simpler reaction conditions, better yields and easier workup are the major benefits of this environmentally friendly procedure.

\section{RESULTS AND DISCUSSION}

5-Benzyl-hydantoin 2 (Table 1) served for the optimization of the reaction conditions. Several ball-milling parameters (type of ball-mill apparatus, material of the jars, speed) were tested, as well as the nature of the base used in the reaction (Table 1). 
The classical conditions of Read synthesis involved a two-step reaction. The hydantoic ester, formed in the first step was cyclized by the addition of an acid in the second step (Scheme 1). Our first objective was to perform an "all-in-one" reaction, in which the hydantoin would be directly formed from the amino ester and potassium cyanate, the ureido intermediate being cyclized in situ in the presence of 2 base equiv.

The first trials were performed in a vibrational ball-mill, using $\mathrm{K}_{2} \mathrm{CO}_{3}$ or $\mathrm{NaHCO}_{3}$ as base (Table 1 , entries 1 and 2 ). In contrast with potassium carbonate, which showed no efficiency, $\mathrm{NaHCO}_{3}$ afforded a good conversion of the substrate into the ureido-derivative $\mathbf{1}$. However, the cyclization to hydantoin 2 did not occur, as shown by LC-MS analysis of the crude. Speculating that more energetic conditions and longer reaction times were necessary for a successful cyclization, the reaction was tested in a planetary ball-mill, using a stainless steel jar under continuous milling (Table 1, entry 3). However, no improvements were observed neither in terms of conversion of substrate nor formation of hydantoin 2. Starting from our previous findings, ${ }^{53,56}$ cycled milling was also tested using stainless steel (Table 1, entry 4) or tungsten carbide (entry 5) jar. In both cases, the conversion of starting material was increased to the same extent, in favor of the ureido-derivative $\mathbf{1}$, also indicating that the different stress phenomena provided by the nature of jar material were not important. However, the cyclization step did not proceed even on prolonged milling, only traces of hydantoin 2 were detected in the crude (entries 4 and 5). The physicochemical properties of the inorganic base, under solvent-free conditions, could have been responsible for the in situ unsuccessful cyclization. Then, $\mathrm{K}_{2} \mathrm{CO}_{3}$ or triethylamine (up to 4 equiv) were added into the jar and cycled milling was maintained at $500 \mathrm{rpm}$ for $4 \mathrm{~h}$, without any success (entries 6 and 7 respectively). To better come out of this failure, the cyclization step needed to be investigated separately starting from the ureido-derivative $\mathbf{1}$.

Therefore, water was added to the milling jar, the phenylalanine ureido-derivative 1 precipitated and it was recovered pure by filtration. To our surprise, the TLC analysis of the filtrate showed the presence of a new compound, which was identified by LC-MS as the desired hydantoin 2 , thus highlighting the need of water in the reaction mixture to promote cyclization.

Starting from this preliminary observation the cyclization step was thus investigated in the presence of water (entry 8). The phenylalanylurea $\mathbf{1}$ was suspended in water and a large excess of triethylamine was added. The homogeneous mixture was left at room temperature, affording 5-benzyl-hydantoin 2 with $90 \%$ conversion (entry 8 ). The experiment was repeated in ball-milling conditions using a triethylamine/water mixture (entry 9). The ureido-derivative 1 was obtained with poor conversion, suggesting that the inorganic base $\mathrm{NaHCO}_{3}$ was fundamental and necessary to drive the reaction toward the almost quantitative formation of the ureido-intermediate. Disappointingly, the use of a triethylamine/water mixture led to a moderate, but however better, conversion to 5-benzylhydantoin 2 , suggesting that instead of a one-pot procedure, a one-pot/two-step methodology ${ }^{58-61}$ would be more appropriate (entry 10). In the first step, the phenylalanine methyl ester hydrochloride was ball-milled with $\mathrm{NaHCO}_{3}$ (entry 10). The ureido-derivative $\mathbf{1}$ was obtained in a very good conversion, in a shorter time $(3 \mathrm{~h}$ instead of $6 \mathrm{~h}$ ) and at a lower milling power (300 rpm instead of $500 \mathrm{rpm}$ ). Then, a triethylamine/water mixture was added to the jar (entry 10, step 2). After ball-milling, the corresponding hydantoin 2 was obtained in a moderate conversion (31\%), which could be explained, in comparison with the solution-synthesis in water, by the shorter time of the mechanochemical reaction $(24 \mathrm{~h}$ against $6 \mathrm{~h}$ respectively). However, our objective being to provide a simple and rapid access to hydantoins, a prolonged time of more than $6 \mathrm{~h}$ of reaction would not be satisfying, which led us to look for better reaction conditions.

Keeping in mind from the literature that the cyclization reaction in solution was usually carried out with diluted alcoholic $\mathrm{HCl}$ at reflux for $2 \mathrm{~h}^{6}{ }^{6}$ we tried to perform the cyclization step in acidic medium, starting from the ureidophenylalanyl derivative $\mathbf{1}$ in the presence of $p$-toluene sulfonic acid (PTSA, 3 equiv). The cyclization did not occur in the ballmilling conditions, confirming the need of basic conditions also for the cyclization step. Within this perspective, it appeared to us that since water seemed to be fundamental for the cyclization step, it had to come into play as a proton donor in a general acid catalysis mechanism, ${ }^{62-64}$ helping the removal of the methanolate of the ester moiety of the ureido-derivative 1. To confirm this hypothesis, liquid-assisted grinding (LAG) was tested in the cyclization step adding nonprotic solvents (ethyl acetate and dichloromethane) or a protic solvent (ethanol) to the reaction mixture $(\eta=1.25 \mu \mathrm{L} / \mathrm{mL})$. In presence of AcOEt, the yield remained comparable to the solventless conditions (81\%), whereas the presence of $\mathrm{CH}_{2} \mathrm{Cl}_{2}$ made it drop to $48 \%$, as the ureido derivative 1 was not fully converted as shown by LC-MS analysis. As expected, adding $\mathrm{EtOH}$ enabled to get the hydantoin in a higher yield of $95 \%$. Not only the last result confirms the idea of a general acid catalysis of the reaction by a proton donor species, but the tests performed in the presence of AcOEt or $\mathrm{CH}_{2} \mathrm{Cl}_{2}$ opened some questioning on their specific effect in these LAG-assisted mechanosyntheses: indeed, the divergent yields obtained for the two trials may result from the incoming solubility of the desired cyclized product hydantoin $\mathbf{2}$ in ethyl acetate (soluble) or in dichloromethane (insoluble). When the reaction proceeds in the presence of AcOEt, the reaction may be driven by the passage of the product in the organic layer, whereas in the presence of $\mathrm{CH}_{2} \mathrm{Cl}_{2}$, insolubility would prevent the cyclization step.

In a green chemistry perspective and considering the previous results, it was necessary to keep at the minimum the use of (flammable) solvents and the number of reactants (as well as their relative stoichiometry) to perform the synthesis. For this reason, instead of adding an extra base to generate the free amino group of phenylalanine methyl ester responsible for the nucleophilic attack on the cyanate, the base was generated in situ exploiting the degradation of a second equivalent of potassium cyanate in water (Scheme 2). Since water seemed to be fundamental, the reaction was explored in aqueous basic solution, and the results were compared to those obtained in the planetary ball-mill (Table 2).

Phenylalanine methylester hydrochloride was reacted with an excess of potassium cyanate in water at room temperature (Table 2, entries 1 and 2). The corresponding phenylalanyl urea 1 precipitated ( $88 \%$ conversion) in less than $2 \mathrm{~h}$. The suspension was kept under stirring, affording the hydantoin 2 after 7 days (entry 1). The kinetic and yield were dependent on the equivalents of potassium cyanate introduced (entries 1 and 2 ), and so on the quantity of in situ generated base, suggesting that the synthesis could be accelerated with an additional amount of base. Hydantoin 2 was obtained in a shorter reaction 
Scheme 2. In Situ Base Formation via Degradation of Potassium Cyanate with Water<smiles>CNC(Cc1ccccc1)C(=O)OC</smiles>

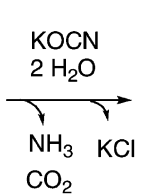<smiles>COC(=O)[C@H](N)Cc1ccccc1</smiles>

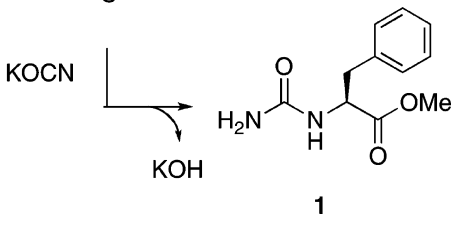

time when a large excess (20 equiv; Table 2, entry 2 ) of KNCO was used (i.e., more in situ generated base), but the yield was lower, due to a more important basic hydrolysis of the methyl ester group.

The addition of $\mathrm{KOH}$ ( 1 equiv) to the solution after $2 \mathrm{~h}$ from the beginning of the reaction (Table 2, entry 3 ) gave similar results, confirming again that a base was necessary for a faster kinetic in water. Then the reaction was tested in the planetary mill, without addition of any supplementary base and increasing the relative ratio $\mathrm{KNCO} / \mathrm{H}_{2} \mathrm{O}$ (Table 2, entry 4). Pure phenylalanylurea 1 was obtained in high yield (97\%, Table 2 , entry 4) without need of purification. The ureido-derivative 1 could be recovered by precipitation by addition of $10 \%$ aqueous citric acid. From an environmental point of view, regarding notably atom and solvent economy, this procedure for the preparation of urea derivative was very advantageous.

The synthesis of urea derivatives in solution was described by Dakin from free amino acids and potassium cyanate, using water as solvent. ${ }^{65}$ An excess of potassium cyanate and heating were necessary to afford phenylalanylurea in $78 \%$ yield. $^{66}$ Microwave irradiation was also used to obtain urea derivatives in $78-90 \%$ yield, with heating at $80{ }^{\circ} \mathrm{C}$ in this case as well. ${ }^{67}$ The synthesis from amino esters ${ }^{68}$ and especially proline methyl ester ${ }^{69}$ was also reported. However, this particular reaction was performed in chloroform to afford the urea compound in only $69 \%$ yield. As far as we know, there is not much published in the area of mechanochemical solvent-free or liquid assisted grinding (LAG) synthesis of (thio)urea derivatives. $^{70-72}$

On the basis of the observations issued from the data reported in Table 1 and with further optimization, a mechanochemical one-pot/two-step procedure using stoichiometric amounts of reagents (Table 2, entry 6), with a 1:2 ratio $\mathrm{KNCO} / \mathrm{H}_{2} \mathrm{O}$ was tested. Finally, phenylalanyl methyl ester hydrochloride was fully converted into the corresponding ureido-derivative $\mathbf{1}$, thanks to the in situ generation of the two needed equivalents of potassium hydroxide (Scheme 2). The cyclization reaction leading to the hydantoin $\mathbf{2}$ occurred in the second step by adding $\mathrm{K}_{2} \mathrm{CO}_{3}$ ( 1 equiv) (Table 2 , entry 6), which was selected instead of $\mathrm{KOH}$ (entry 5), because of less risk of epimerization or ester hydrolysis. ${ }^{25}$

The synthesis of phenylalanyl urea 1 could be achieved with comparable results in terms of kinetics and yields, in both aqueous solution or planetary-mill conditions. In the case of hydantoin, the reaction in water was slower than the mechanochemical one and a very large excess of reactants needed to be used, which is not desirable from the environmental point of view. On the basis of these findings, ball-milling was selected as the method of choice for the synthesis of a library of 5-substituted- and 5,5-disubstitutedhydantoins, as well as 6-membered heterocycles, starting from $\alpha$-amino methyl esters, quaternary amino methyl esters or $\beta$ amino methyl esters respectively (Table 3 ). 2- and 3aminoisobutyric methyl ester hydrochlorides were prepared from the corresponding amino acids by reaction with an excess of trimethylsilyl chloride (TMSCl) in methanol, under stirring for 3 days (yields $97 \%$ and $75 \%$ respectively, see Supporting Information). It turned out that although the substrates were very easily converted into their urea derivatives in the first step, with a reaction time extended to $120 \mathrm{~min}$ (instead of $90 \mathrm{~min}$ as for $\mathrm{HCl} \cdot \mathrm{H}-\mathrm{Phe}-\mathrm{OMe}$, Table 3, entry 1 ), the conditions for the second step had to be adjusted according to the starting amino

Table 2. Comparison for the Synthesis of Hydantoin in Water and in a Ball-Mill<smiles>COC(=O)C(Cc1ccccc1)NO</smiles>

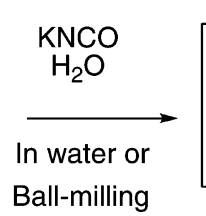<smiles>COC(=O)C(Cc1ccccc1)NC(N)=O</smiles>

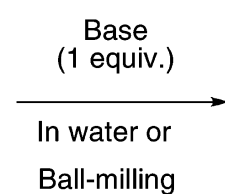

Ball-milling

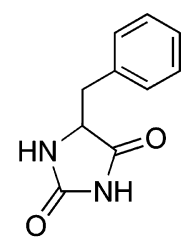

2

\begin{tabular}{|c|c|c|c|c|c|c|c|}
\hline \multirow[b]{2}{*}{ entry } & \multirow[b]{2}{*}{ method } & \multirow[b]{2}{*}{$\mathrm{KNCO} / \mathrm{H}_{2} \mathrm{O}$ (equiv) } & \multirow[b]{2}{*}{ base } & \multicolumn{2}{|c|}{ conditions (h) } & \multicolumn{2}{|c|}{ yield (\%) } \\
\hline & & & & step 1 & step 2 & 1 & 2 \\
\hline 1 & $\mathrm{CS}^{a}$ & $5 / 720$ & / & 168 & / & n.i. ${ }^{b}$ & 76 \\
\hline 2 & $\mathrm{CS}^{a}$ & $20 / 720$ & / & 18 & / & n.i. ${ }^{b}$ & 58 \\
\hline 3 & $\mathrm{CS}^{a}$ & $20 / 720$ & $\mathrm{KOH}^{c}$ & 2 & 3 & n.i. ${ }^{b}$ & 77 \\
\hline 4 & $\mathrm{BM}^{d}$ & $20 / 40$ & / & $1.5^{d, e}$ & n.p. ${ }^{b}$ & 97 & n.o. ${ }^{b}$ \\
\hline 5 & $\mathrm{BM}^{d}$ & $10 / 40$ & $\mathrm{KOH}$ & $3^{d, e}$ & $3^{e, f}$ & n.i. ${ }^{b}$ & 84 \\
\hline 6 & $\mathrm{BM}^{d}$ & $3 / 4$ & $\mathrm{~K}_{2} \mathrm{CO}_{3}$ & $1.5^{c, d}$ & $1.5^{e, f}$ & n.i. ${ }^{b}$ & 80 \\
\hline
\end{tabular}

${ }^{a}$ The reaction was performed in water at room temperature under stirring, and the base was generated in situ; CS $=$ Classical Stirring. ${ }^{b}$.i. $=$ not isolated, n.o. = not observed, n.p. = not performed. ${ }^{{ }^{c}}$ The base was added after $2 \mathrm{~h}$ under stirring at room temperature. ${ }^{d} \mathrm{BM}=\mathrm{Ball}-\mathrm{milling}$; Typical procedure. Step 1: L-phenylalanine methyl ester hydrochloride (1 equiv) and KNCO (equiv as detailed in the Table) were reacted in a planetary ballmill ( $12 \mathrm{~mL}$ stainless steel jar, 25 stainless steel balls, $5 \mathrm{~mm}$ diameter) at $450 \mathrm{rpm}$ for the specified time. ${ }^{e} \mathrm{Cycled}$ milling of 10 min cycles followed by 5 min of standby in between, with reverse rotation. ${ }^{f}$ Step 2 : The base (1 equiv) was added, and the milling was repeated in the same conditions as Step 1 (450 rpm), with cycled milling, for the specified time. 
Table 3. Synthesis of 5-Substituted-, 5,5-Disubstituted Hydantoins and Six-Membered Heterocycles ${ }^{a}$
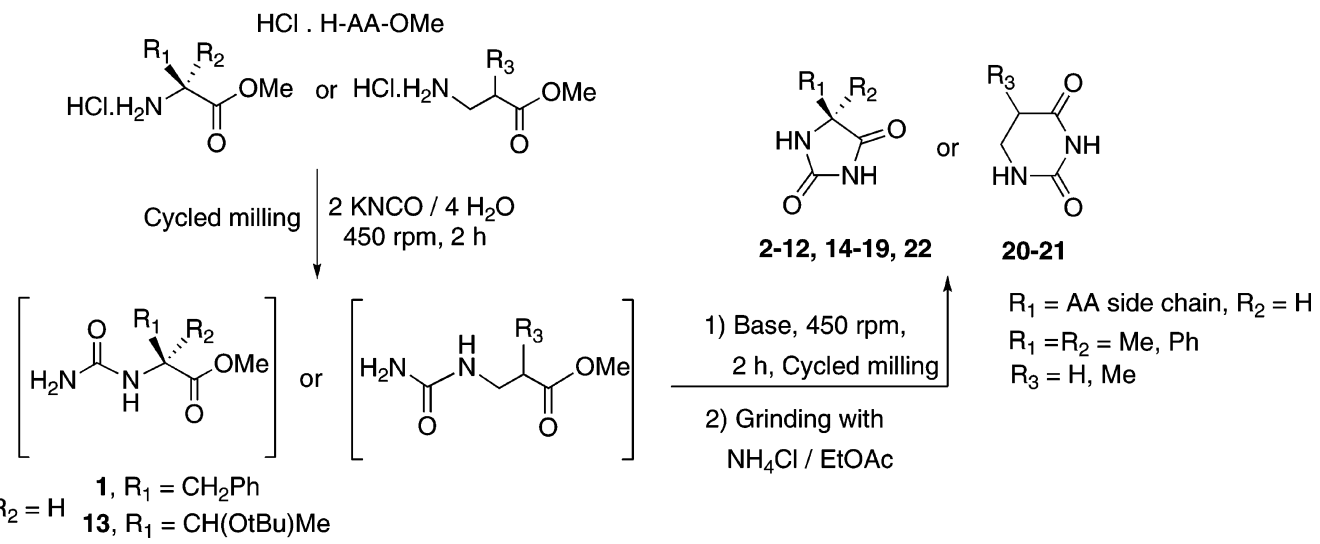

$\mathrm{NH}_{4} \mathrm{Cl} / \mathrm{EtOAC}$

\begin{tabular}{|c|c|c|c|}
\hline entry & HCl.H-AA-OMe & compound & yield (\%) \\
\hline $1^{b}$ & $\mathrm{~L}-\mathrm{HCl} \cdot \mathrm{H}-\mathrm{Phe}-\mathrm{OMe}{ }^{b}$ & 1 & $97^{b}$ \\
\hline 2 & $\mathrm{~L}-\mathrm{HCl} \cdot \mathrm{H}-\mathrm{Phe}-\mathrm{OMe} \mathrm{e}^{c}$ & 2 & $(80)^{d}$ \\
\hline 3 & D-HCl-H-Phe-OMe & 3 & $70^{f}$ \\
\hline 4 & $\mathrm{~L}-\mathrm{HCl} \cdot \mathrm{H}-\mathrm{Tyr}\left(\mathrm{O}^{t} \mathrm{Bu}\right)-\mathrm{OMe}$ & 4 & $100(53)^{d}$ \\
\hline 5 & L-HCl-H-Met-OMe & 5 & $(91)^{d}$ \\
\hline 6 & L-HCl-H-Cys(Bn)-OMe & 6 & 84 \\
\hline 7 & L-HCl·H-Ala-OMe & 7 & $79(53)^{d}$ \\
\hline 8 & $\mathrm{~L}-\mathrm{HCl} \cdot \mathrm{H}-\mathrm{Val}-\mathrm{OMe}$ & 8 & $94(69)^{d}$ \\
\hline 9 & L-HCl·H-Ile-OMe & 9 & $85(53)^{d, e}$ \\
\hline 10 & $\mathrm{D}-\mathrm{HCl} \cdot \mathrm{H}-\mathrm{Leu}-\mathrm{OMe}$ & 10 & $93(56)^{d}$ \\
\hline 11 & $\mathrm{~L}-\mathrm{HCl} \cdot \mathrm{H}-\mathrm{Ser}\left(\mathrm{O}^{t} \mathrm{Bu}\right)-\mathrm{OMe}$ & 11 & 100 \\
\hline $12^{b}$ & $\mathrm{~L}-\mathrm{HCl} \cdot \mathrm{H}-\mathrm{Thr}\left(\mathrm{O}^{t} \mathrm{Bu}\right)-\mathrm{OMe}{ }^{b}$ & 12 & $96^{b}$ \\
\hline 13 & $\mathrm{~L}-\mathrm{HCl} \cdot \mathrm{H}-\mathrm{Thr}\left(\mathrm{O}^{t} \mathrm{Bu}\right)-\mathrm{OMe}$ & 13 & 96 \\
\hline 14 & L-HCl·H-Phg-OMe & 14 & $97^{f}$ \\
\hline 15 & $\mathrm{~L}-\mathrm{HCl} \cdot \mathrm{H}-\mathrm{Asp}(\mathrm{OMe})-\mathrm{OMe}$ & 15 & 32 \\
\hline 16 & L-HCl·H-Lys(Z)-OMe & 16 & 91 \\
\hline 17 & L-HCl-H-Pro-OMe & 17 & $(91)^{f}$ \\
\hline 18 & L-HCl-H-Trp-OMe & 18 & $77^{g}$ \\
\hline 19 & $\mathrm{HCl} \cdot \mathrm{H}-\mathrm{Aib}-\mathrm{OMe}{ }^{h}$ & 19 & $(92)^{d}$ \\
\hline 20 & $\mathrm{HCl} \cdot \mathrm{H}-\beta$-Ala-OMe & 20 & 47 \\
\hline 21 & $\mathrm{HCl} \cdot \mathrm{H}-3-\mathrm{Aib}-\mathrm{OMe}{ }^{i}$ & 21 & 57 \\
\hline 22 & $\mathrm{~L}-\mathrm{HCl} \cdot \mathrm{H}-\mathrm{Gly}(\mathrm{Ph})_{2}-\mathrm{OMe}$ & 22 & $84^{j}$ \\
\hline
\end{tabular}

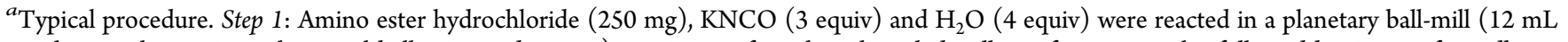
stainless steel jar, 25 stainless steel balls, $5 \mathrm{~mm}$ diameter) at $450 \mathrm{rpm}$ for $2 \mathrm{~h}$ with cycled milling of 10 min cycles followed by $5 \mathrm{~min}$ of standby in between, with reverse rotation; Step 2: $\mathrm{Cs}_{2} \mathrm{CO}_{3}$ (3 equiv) was added, and the milling was repeated in the same conditions as Step 1 (450 rpm), with cycled milling, for $2 \mathrm{~h}$, except when differently stated. ${ }^{b}$ Only Step 1 was performed, using 20 equiv of $\mathrm{KNCO}$ and 40 equiv of $\mathrm{H}_{2} \mathrm{O}$. Yield referred to the ureido-derivative. ${ }^{c}$ Ball-milling was performed during 90 min. ${ }^{d}$ The cyclization step was performed using $\mathrm{K}_{2} \mathrm{CO}_{3}$ ( 1 equiv) ${ }^{e} \mathrm{On}$ the basis of

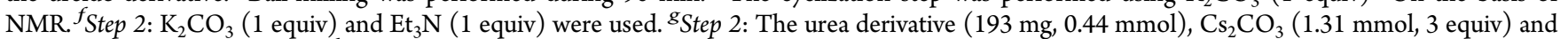
$\mathrm{Et}_{3} \mathrm{~N}(0.44 \mathrm{mmol})$ were used. ${ }^{h} \mathrm{HCl} \cdot \mathrm{H}$-Aib-OMe $\left(\mathrm{R}^{1}=\mathrm{R}^{2}=\mathrm{Me}\right), 2$-amino isobutyric acid methyl ester hydrochloride. ${ }^{i} \mathrm{HCl} \cdot \mathrm{H}-3$-Aib-OMe $\left(\mathrm{R}^{3}=\right.$ $\mathrm{Me}$ ), 3-amino-2-methylpropanoic acid methyl ester hydrochloride. ${ }^{j}$ Trimethylsilyl isocyanate (TMS-NCO (3.60 mmol) was used (see Experimental Section for more details).

ester, particularly concerning the nature of the base used for cyclization (Table 3 ). Indeed, potassium carbonate (1 equiv) was effective for the formation of hydantoins from phenylalanine, methionine and the sterically hindered aminoisobutyric acid methyl esters in very good yields (Table 3, entries 1,5 , and 19 respectively). For 5,5-dimethylhydantoin 19, the yield was doubled (92\%) compared to the synthesis performed in solution according to the Bucherer-Bergs method (45\%), highlighting the performances of the ball-milling approach for recalcitrant substrates. Moreover no synthesis of 5,5-dimethylhydantoin 19 under Read conditions was ever reported, nor of 5-[2-(methylthio)ethyl]-2,4-imidazolidinedione $\mathbf{5}$.

$\mathrm{K}_{2} \mathrm{CO}_{3}$ was less efficient when used with $\alpha$-amino esters having aliphatic side chains [i.e., alanine (entry 7), valine (entry
8), isoleucine (entry 9) and leucine (entry 10)], leading to only partial conversion of the corresponding ureido-precursors, even after extended reaction times (4-6 h). As a consequence, other bases, namely cesium carbonate ( 3 equiv) and triethylamine ( 1 equiv) were explored. In most cases, yields were drastically increased when $\mathrm{Cs}_{2} \mathrm{CO}_{3}$ (3 equiv) was used instead of $\mathrm{K}_{2} \mathrm{CO}_{3}$ (entries 4, 7-10), showing its general efficiency for the cyclization reaction, independently of the nature of amino ester side chain (Table 3, entries 3, 4, 6-12, 14, 16 and 22). Moreover, 5-isopropylhydantoin 8 (entry 8) and 5-isobutylhydantoin 10 (entry 10) were obtained with improved yields compared to solution synthesis, from the corresponding $\alpha$ amino acid precursors with potassium cyanate upon heating at $100{ }^{\circ} \mathrm{C}$ for $2 \mathrm{~h}$ (84\% from $\mathrm{HCl} \cdot \mathrm{H}-\mathrm{Val}-\mathrm{OH}$ and $51 \%$ from $\mathrm{HCl}$. 
Table 4. Comparison between Yields Obtained from the Mechanochemical Pathway and from Solution Synthesis

\begin{tabular}{|c|c|c|c|c|}
\hline \multicolumn{5}{|c|}{ method } \\
\hline compound & mechanochemistry yield $(\%)^{a}$ & in solution & starting material $^{b}$ & yield $(\%)^{b}$ \\
\hline 2 & 80 & $\operatorname{Read}^{c, 6}$ & $\mathrm{H}$-Phe-OH & 92 \\
\hline 3 & 70 & n.p. ${ }^{d}$ & - & - \\
\hline 4 & 100 & n.p. ${ }^{d}$ & - & - \\
\hline 5 & 91 & n.p. ${ }^{d}$ & - & - \\
\hline 6 & 84 & n.p. ${ }^{d}$ & - & - \\
\hline 7 & 81 & $\mathrm{DBP}^{e, 74}$ & NC-NH-Ala-OMe ${ }^{e}$ & 79 \\
\hline 8 & 94 & $\operatorname{Read}^{c, 6}$ & $\mathrm{H}-\mathrm{Val}-\mathrm{OH}$ & 84 \\
\hline 9 & 85 & $\operatorname{Read}^{c, 6}$ & H-Ile-OH & 41 \\
\hline 10 & 93 & $\operatorname{Read}^{c, 6}$ & H-Leu-OH & 51 \\
\hline 11 & 100 & n.p. ${ }^{d}$ & - & - \\
\hline 13 & 96 & n.p. ${ }^{d}$ & - & - \\
\hline 14 & 97 & $\operatorname{Read}^{c, 6}$ & H-Phg-OH & 87 \\
\hline 15 & 32 & $\mathrm{DBP}^{e, 74}$ & $\mathrm{NC}-\mathrm{NH}-\mathrm{Asp}(\mathrm{OMe})-\mathrm{OMe}^{e}$ & 74 \\
\hline 16 & 91 & n.p. ${ }^{d}$ & - & - \\
\hline 17 & 91 & $\mathrm{DBP}^{e, 21}$ & H-Pro-OMe $e^{e}$ & 55 \\
\hline 18 & 77 & $\operatorname{Read}^{c, 75}$ & $\mathrm{H}-\mathrm{Trp}-\mathrm{OH}$ & 77 \\
\hline 19 & 92 & Bucherer-Bergs ${ }^{e, 76}$ & $\mathrm{CH}_{3} \mathrm{COCH}_{3}$ & 95 \\
\hline 20 & 47 & n.p. ${ }^{d}$ & - & - \\
\hline 21 & 57 & $\operatorname{Read}^{77}$ & H-3-Aib-OH & n.s. ${ }^{f}$ \\
\hline 22 & 84 & Biltz $^{2}$ & $(\mathrm{PhCO})_{2}$ & 100 \\
\hline & & $\mathrm{W}(\mathrm{CO})_{6} / \mathrm{CO}^{g, 78}$ & $\mathrm{H}-\mathrm{Gly}(\mathrm{Ph})_{2}-\mathrm{NH}_{2}$ & 64 \\
\hline
\end{tabular}

${ }^{a}$ Amino methyl ester hydrochlorides were the substrates. Reactions performed at room temperature. ${ }^{b_{\text {The }}}$ free amino acids were used as substrates, except where differently specified. ${ }^{c}$ Reaction under reflux with $\mathrm{HCl} 10 \% .{ }^{d}$ n.p. $=$ not performed. ${ }^{e} \mathrm{DBP}$ : $N$-cyano amino methyl esters were used as substrates and reacted with dibutylphosphate (DBP) in toluene or $\mathrm{Et}_{2} \mathrm{O}$ for $2 \mathrm{~h}$ at $110{ }^{\circ} \mathrm{C}$. The reaction was performed under microwaves in a domestic oven. ${ }^{f}$ The yield was not specified (n.s.) in the literature. ${ }^{g}$ Reaction at $45{ }^{\circ} \mathrm{C}$ for $36 \mathrm{~h}^{\text {in }} \mathrm{CH}_{2} \mathrm{Cl}_{2}$ with diazabicycloundecene (DBU) as base.

H-Leu-OH respectively). ${ }^{6}$ Triethylamine was also used in addition to carbonated bases (entries 17 and 18). It may be noticed that the liquid state of triethylamine helped the reaction to proceed, as illustrated in the case of $\mathrm{HCl} \cdot \mathrm{H}$-Trp-OMe (entry 18). Indeed, cyclization was not complete when either cesium carbonate $(24 \%$ yield) or triethylamine were used alone (no reaction for step 2), while the corresponding ureido-derivative was fully converted when the bases were used together. With L$\mathrm{HCl} \cdot \mathrm{H}-\mathrm{Asp}(\mathrm{OMe})-\mathrm{OMe}$ (entry 15 ) as substrate, the hydantoin was obtained in poor yield (32\%), probably because of a side reaction between the methyl ester side chain and the intermediate aspartyl urea. It is worth noting that, unexpectedly, the reactivity of L- or D-phenylalanyl amino esters (entries 1 and 3 respectively) was not exactly the same. Indeed, when the stereoisomer L afforded 5-benzyl hydantoin 2 smoothly using $\mathrm{K}_{2} \mathrm{CO}_{3}$ (within $90 \mathrm{~min}$ ), $\mathrm{Et}_{3} \mathrm{~N}$ and longer reaction time (120 $\mathrm{min}$ ) were necessary for the cyclization step from the $\mathrm{D}$ enantiomer. Six-membered heterocycles, namely dihydrouracil (DHU) 20 and dihydrothymine (DHT) 21, were also synthesized starting from the corresponding $\beta$-aminoester precursors (entries 20 and 21); however, despite the full conversion of the ureido-derivative, the yield remained moderate. In all cases, the final products were recovered pure after a straightforward and simple workup without need of chromatographic purification or recrystallization. No byproduct was formed, the only waste being inorganic salts $(\mathrm{KCl}$ or $\mathrm{CsCl})$, water, gases $\left(\mathrm{CO}_{2}\right.$ and $\left.\mathrm{NH}_{3}\right)$ and $\mathrm{MeOH}$ (easily eliminated by evaporation). 5-Phenylhydantoin $\mathbf{1 4}$ was obtained in slightly better yield $(97 \%)$ than in the Read solution synthesis $(87 \%$, heating at $\left.100{ }^{\circ} \mathrm{C}\right),{ }^{6}$ and recrystallization was not necessary. Except for 5-benzylhydantoin 2, 5-phenylhydantoin 14 and tryptophan derivative 18 (Table 3, entries 2, 14 and 18), hydantoins were very soluble in water, preventing their recovery by precipitation or extraction. The final products were thus recovered by eliminating the inorganic salts by precipitation: 10 equiv of $\mathrm{NH}_{4} \mathrm{Cl}$ (prior to the amino ester) and $2 \mathrm{~mL}$ of ethyl acetate were added to the jar (solvent-assisted grinding) $)^{73}$ and ball-milled for 3 cycles of $10 \mathrm{~min}$ (with a $5 \mathrm{~min}$ standby between each cycle). The precipitate and the milling balls were transferred into a round-bottom flask containing 50 $\mathrm{mL}$ of EtOAc and left under stirring until the salts were completely removed from the balls. The suspension was filtered to eliminate the inorganic salts, with the organic phase containing the desired pure hydantoin. This procedure also allowed elimination, as a precipitate, of any trace of residual unreacted amino ester hydrochloride (when present).

From the point of view of a benign chemistry, the abovedescribed synthetic procedure (and workup) presents many advantages with respect to the literature procedures: (i) it is a very general method, particularly adapted for the synthesis of 5and 5,5-disubstituted hydantoins from readily available amino esters; (ii) mild reaction conditions (room temperature) are always used; (iii) in most of the cases, yields are better, compared to synthesis in solution; (iv) the quantity of waste is reduced, avoiding the use of an excess of reagents or solvents (including those used to recrystallize the final product), reducing the environmental impact (Table 4).

It was surprising to notice that for all the methods described in solution using basic conditions, the investigation of the optical purity of the 5-substituted hydantoins has never been reported.

Indeed, to the best of our knowledge, no chiral HPLC analyses for hydantoin syntheses have been furnished so far. LPhenylalanyl hydantoin 2 was used as benchmark, and chiral HPLC analyses were also performed on the ureido-derivative precursor 1 , in order to verify the preservation of the optical 
purity of the compounds. In the first step (Scheme 2), the synthesis of L-phenylalanyl urea $\mathbf{1}$ occurred in the presence of in situ-generated two equivalents of $\mathrm{KOH}$ and gaseous $\mathrm{NH}_{3}$, which could be responsible for the epimerization. Speculating that reactants in gas phase displayed limited reactivity under mechanochemical conditions, ${ }^{79}$ being constantly displaced at impact with the balls and never combining with the other reagents into the jar, while one equivalent of $\mathrm{KOH}$ was involved in the reaction with the amino ester hydrochloride, epimerization could occur in this step by action of the remaining equivalent of $\mathrm{KOH}$. However, chiral HPLC analyses (see Supporting Information) showed that L-phenylalanyl urea 1 was optically pure after the first step. On the contrary, the presence of potassium carbonate used in the cyclization step led to phenylalanyl hydantoin 2 with 90:10 enantiomeric ratio (e.r.). Speculating that epimerization occurred in the second step because of $\mathrm{KOH}$ already present in the crude (after the first step), the reaction was repeated and $\mathrm{NH}_{4} \mathrm{Cl}$ (1 equiv) was added to the jar and ball-milled for $30 \mathrm{~min}$ after the first step, to neutralize the extra equivalent of $\mathrm{KOH}$. However, after cyclization, the e.r. was not improved, while the yield remained the same. When chiral HPLC analyses were performed on the alanine derivative 7 (Table 2, entry 7), an 86:14 enantiomeric ratio was obtained. This unexpected behavior deserves further investigations and results will be reported in the due course.

Relying on the efficiency and generality of the method, successfully applied to the sterically hindered amino ester $\mathrm{HCl}$. H-Aib-OMe (Table 3, entry 19), diphenylglycine methyl ester hydrochloride (Table 3, entry 22) was also investigated as substrate, with the objective to prepare the antiepileptic drug Phenytoin 22 (marketed as Phenytek by Mylan, USA). The methyl ester was first prepared by refluxing the amino acid with a large excess of $\mathrm{SOCl}_{2}$ in methanol, and then engaged in the synthesis of phenytoin (see Supporting Information). The first trials were unsuccessful, even using a large excess of reactants ( 20 equiv of $\mathrm{KNCO}, 40$ equiv of $\mathrm{H}_{2} \mathrm{O}$ ) and dramatic increase of milling speed $(700 \mathrm{rpm})$ : no conversion of the substrate was observed. Trimethylsilyl isocyanate (TMS-NCO), a more reactive alternative to potassium cyanate was considered (Scheme 3). To our delight, this attempt was successful. Although the conversion of the substrate was incomplete, the formation of the ureido-derivative from 5,5-diphenylglycine methyl ester hydrochloride was possible using 3 equiv of TMSNCO. Again, the decomposition of trimethylsilyl isocyanate in the presence of water ${ }^{80}$ accounts for the in situ generation of the (liquid) base hexamethyldisilazane (HMDS) in the presence of $\mathrm{HCl}$ (provided here by the amino methyl ester hydrochloride), leading also to the formation of the amino nucleophile. Therefore, water was once again essential to the reaction allowing the generation of the base as well as, in a second step, the hydrolysis of the $N$-protected trimethylsilyl ureido-derivative A of 5,5-diphenylglycine methyl ester (Scheme 3).

Grinding this intermediate with cesium carbonate ( 3 equiv), as already described (Table 3), afforded Phenytoin 22, with full conversion of the intermediate. The limiting step of the reaction being the nucleophilic addition of the amino group onto the isocyanate, a large excess of a 1:1 mixture of TMS$\mathrm{NCO} / \mathrm{H}_{2} \mathrm{O}$ (20 equiv) was used with cycled milling, leading to Phenytoin 22 in $84 \%$ yield after eco-friendly workup, as previously described (Table 3, entry 22 and Scheme 3 ). The residual unreacted $\alpha, \alpha$-diphenylglycine methyl ester was
Scheme 3. Water-Assisted Mechanochemical Synthesis of Phenytoin 22
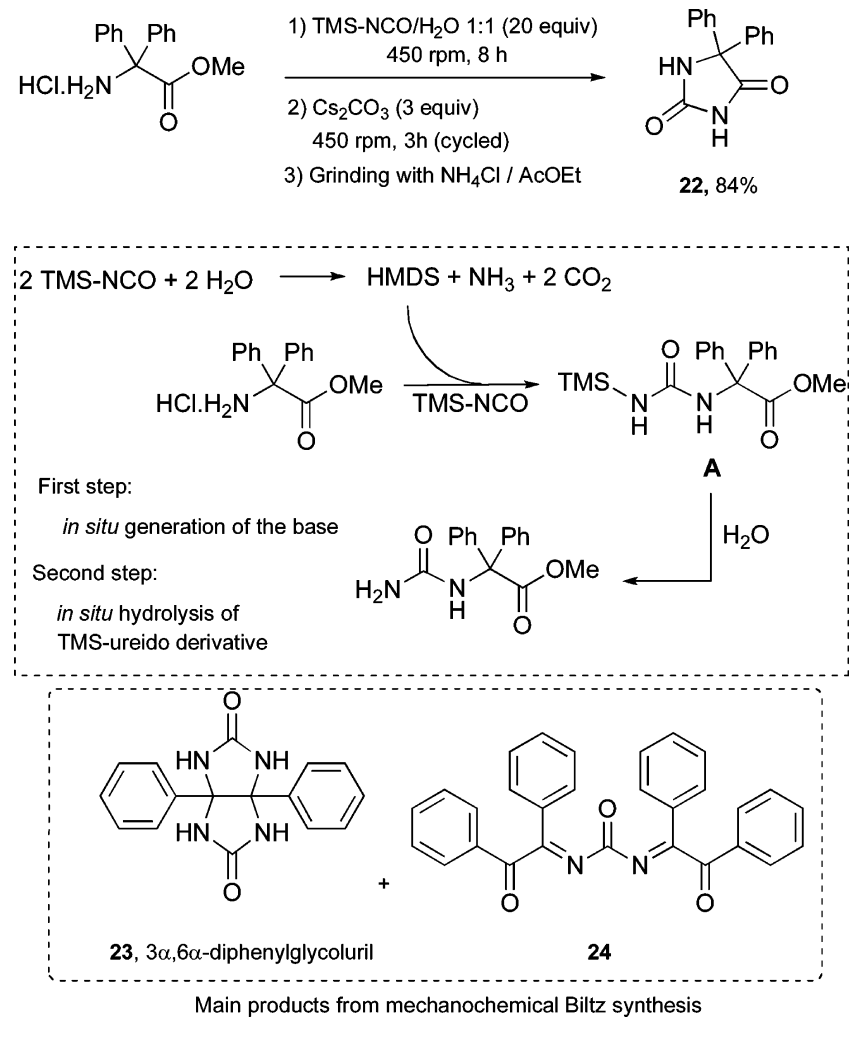

eliminated by washing the final product with water, and the volatile trimethylsilane by evaporation.

Phenytoin was historically synthesized from the condensation of benzil and urea according to the Biltz reaction, ${ }^{7,31}$ remaining the principally used pathway to its obtention. A few papers reported the formation of phenytoin in solution from the corresponding $\alpha$-amino amide ( $\alpha, \alpha$-diphenylglycamide) via an heterogeneous tungsten-catalyzed carbonylative cyclization ${ }^{78}$ (64\% yield after column chromatography, Table 4). $\alpha, \alpha$ Diphenylglycine ethyl ester and aryl isocyanates ${ }^{81}$ were used for the synthesis of $\mathrm{N}$-substituted phenytoin derivatives, but no data were reported for the preparation of phenytoin from amino ester precursors. These procedures suffered of constraining conditions (metal-mediated synthesis and handling of gaseous $\mathrm{CO}$ ), expensive and/or numerous reagents (e.g., the synthesis of $\alpha$-amino amide), and organic solvents (for workup and purification by column chromatography). When the Biltz synthesis (Scheme 1) was achieved without solvent in a vibrational ball-mill at $30 \mathrm{~Hz}$ for $2 \mathrm{~h}$, phenytoin was obtained in only $10 \%$ yield. The major products of the reaction were the $3 \alpha, 6 \alpha$-diphenylglycoluril derivative 23 and the 1,3-bis(2-oxo1,2-diphenylethylidene) urea $\mathbf{2 4}$ issued from the double condensation of benzil with urea (See Scheme 3). In solution, it was commonly accepted that the mechanism for the formation of phenytoin $\mathbf{2 2}$ goes through a pinacol rearrangement with a 1,2-shift of a phenyl group, ${ }^{31}$ while the glycoluril byproduct was formed by a double condensation of urea with benzil. It is interesting to observe that although the rearrangement was the favorite pathway in solution, the mechanochemical activation switched the selectivity toward the formation of glycoluril 23 and double condensation product 1,3-bis(2-oxo1,2-diphenylethylidene) urea $\mathbf{2 4}$ as the main products. To compare the mechanical effects of the grinding on the outcome 
of the reaction, ${ }^{39}$ we also tested the Biltz synthesis in a planetary ball-mill. At low rotation speeds (100 and $200 \mathrm{rpm}$ ), the grinding was not efficient and benzil and urea remained unreacted. However, at $450 \mathrm{rpm}$ (for $30 \mathrm{~min}$ ) partial conversion of benzil afforded phenytoin 22 in $44 \%$ yield, together with the formation of $\mathbf{2 3}$ and $\mathbf{2 4}$, as well as other nonidentified byproducts (Scheme 3 ). Our synthetic methodology for obtaining phenytoin under liquid assisted mechanochemical activation was thus validated by the facts that (i) the Biltz reaction under ball-milling conditions did not afford phenytoin in good yield, and (ii) our procedure did not generate any undesired byproduct such as $3 \alpha, 6 \alpha$-diphenylglycoluril 23 observed in the Biltz synthesis.

\section{CONCLUSION}

A novel technological achievement for the preparation of 5- and 5,5-disubstituted hydantoins from amino esters and potassium cyanate was described. The procedure is general and very advantageous to prepare libraries of five- or six-membered heterocycles, including dihydrothymine and dihydrouracile, in good to excellent yields. From an environmental point of view, no solvent, no excess of reagents or purification steps were necessary. In particular, the methodology was successfully applied to the preparation of the antiepileptic drug phenytoin in good yield, as the only cheap alternative to Biltz synthesis under mechanochemical conditions, opening new frontiers for safe and eco-friendly synthesis of pharmaceutically interesting drug on large scale.

\section{EXPERIMENTAL SECTION}

General Remarks and Experimental Procedures. All reagents were commercially available and used without any further purification. NMR spectra were recorded at room temperature with the appropriate deuterated solvent $\left(\mathrm{CD}_{3} \mathrm{CN}\right.$ or DMSO- $\left.d_{6}\right)$. Chemical shifts $(\delta)$ of ${ }^{1} \mathrm{H}$ NMR and ${ }^{13} \mathrm{C}$ NMR spectra are reported in ppm relative to residual solvent signals $\left(\mathrm{CHCl}_{3}\right.$ in $\mathrm{CDCl}_{3}: \delta=7.27 \mathrm{ppm}$ for ${ }^{1} \mathrm{H}$ and $\mathrm{CDCl}_{3}: \delta$ $=77.04 \mathrm{ppm}$ for ${ }^{13} \mathrm{C}$ NMR); $J$ values are given in $\mathrm{Hz} .{ }^{1} \mathrm{H}$ and ${ }^{13} \mathrm{C}$ NMR spectra were registered at 300 or $400 \mathrm{MHz}$. The identity of analytically pure final products was assessed by comparison of their ${ }^{1} \mathrm{H}$ NMR data previously described in the literature and by their fragmentation in LC-MS. HRMS measurements were performed on a TOF mass analyzer. Analytical high performance liquid chromatography (HPLC) was performed with a variable wavelength diode detector using a CHROMOLITH RP18 column $(50 \times 4.6 \mathrm{~mm})$, flow $5 \mathrm{~mL} / \mathrm{min}$, linear gradient $\mathrm{CH}_{3} \mathrm{CN}$ in water $0-100 \%(+0.1 \%$ TFA $)$ in 4.5 min. LC-MS analysis were performed with HPLC, column Onyx $\mathrm{C}_{18},(25 \times 4.6 \mathrm{~mm})$, flow $3 \mathrm{~mL} / \mathrm{min}$ linear gradient $\mathrm{CH}_{3} \mathrm{CN}$ in water $0-100 \%\left(+0.1 \% \mathrm{HCO}_{2} \mathrm{H}\right)$ in $2.5 \mathrm{~min}$. The ball-milling experiments were performed in a MM200 vibrational ball (Retsch $\mathrm{GmbH}$, Haan, Germany) using $10 \mathrm{~mL}$ mill steel jar (2 stainless steel balls, $5 \mathrm{~mm} \varnothing$ ), or PM100 planetary mill (Retsch GmbH, Haan, Germany) $12 \mathrm{~mL}$ steel jar $(12,24,36$, or 50 stainless steel balls, $5 \mathrm{~mm} \varnothing)$ or $50 \mathrm{~mL}$ tungsten carbide (WC) jar (50 tungsten carbide balls, $5 \mathrm{~mm} \varnothing$ ). For tests at $700 \mathrm{rpm}$, Fritsch Pulverisette 7 Premium Line planetary mill (Fritsch $\mathrm{GmbH}$, Idar-Oberstein, Germany) using a $20 \mathrm{~mL}$ stainless steel jar (50 stainless steel balls, $5 \mathrm{~mm} \varnothing$ ) was used. All compounds displayed identical spectral data compared to literature.

(S)-Methyl $\mathrm{N}$-(aminocarbonyl)phenylalaninate 1 (Table 3, entry 1). CAS [928035-69-2]. Method A: L-phenylalanine methyl ester hydrochloride $(500 \mathrm{mg}, 2.32 \mathrm{mmol})$, potassium cyanate $(3.8 \mathrm{~g}$, $46.4 \mathrm{mmol}, 20$ equiv) and deionized water $(92.80 \mathrm{mmol}, 1.67 \mathrm{~mL}, 40$ equiv) were ball-milled in a $12 \mathrm{~mL}$ stainless steel milling jar with 25 stainless steel milling balls ( $5 \mathrm{~mm}$ diameter). The mixture was ground at $500 \mathrm{rpm}$ for 6 cycles of milling of $10 \mathrm{~min}$, with a 5 min pause in between each cycle, with reverse rotation. $10 \%$ aqueous citric acid was then added to the crude until $\mathrm{pH}=6$, and the aqueous layer extracted with ethyl acetate $(3 \times 8 \mathrm{~mL})$. The organic layer was dried over $\mathrm{MgSO}_{4}$, filtered under vacuum, concentrated and dried over $\mathrm{P}_{2} \mathrm{O}_{5}$. Diethyl ether was added to the resulting oil, and the product precipitated as white crystals. (500 mg, $2.25 \mathrm{mmol}, 97 \%$ yield). Method $B$ : L-phenylalanine methyl ester hydrochloride $(500 \mathrm{mg}, 2.32 \mathrm{mmol})$, potassium cyanate $(941 \mathrm{mg}, 11.6 \mathrm{mmol}, 5$ equiv and deionized water (9.28 mmol, $167 \mu \mathrm{L}, 4$ equiv) were ball-milled in a $12 \mathrm{~mL}$ stainless steel milling jar with 25 stainless steel milling balls ( $5 \mathrm{~mm}$ diameter). The mixture was ground at $500 \mathrm{rpm}$ for 6 cycles of milling of $10 \mathrm{~min}$, with a $5 \mathrm{~min}$ pause in between each cycle, with reverse rotation. The crude was transferred on a sintered glass and washed with ethyl acetate $(20 \mathrm{~mL})$, and the organic layer was filtered under vacuum, concentrated and dried over $\mathrm{P}_{2} \mathrm{O}_{5}$, to afford a white solid, which was dried over $\mathrm{P}_{2} \mathrm{O}_{5}$. (420.4 mg, 82\% yield); ${ }^{1} \mathrm{H}$ NMR (300 MHz, DMSO- $\left.d_{6}\right) \delta(\mathrm{ppm}) 2.91(\mathrm{~m}, 2 \mathrm{H}), 4.38(\mathrm{q}, 1 \mathrm{H}, J=7.9 \mathrm{~Hz}), 5.64(\mathrm{~s}$, $2 \mathrm{H}), 6.29(\mathrm{~d}, 1 \mathrm{H}, J=8.1 \mathrm{~Hz}), 7.15-7.31(\mathrm{~m}, 5 \mathrm{H}) ;{ }^{66}{ }^{13} \mathrm{C}\left\{{ }^{1} \mathrm{H}\right\} \mathrm{NMR}$ $\left(300 \mathrm{MHz}, \mathrm{DMSO}-d_{6}\right) \delta(\mathrm{ppm}) 7.7,53.9,126.5,128.3,129.1,129.7$, 137.2, 157.9, 173.1; ESI- $(+) \mathrm{m} / z 223[\mathrm{M}+\mathrm{H}]^{+}, 245[\mathrm{M}+\mathrm{Na}]^{+}, 180$.

(5S)-(Phenylmethyl)-2,4-imidazolidinedione 2 (Table 3, entry 2). CAS [3530-82-3]. Step 1: L-phenylalanine methyl ester hydrochloride $(250 \mathrm{mg}, 1.16 \mathrm{mmol})$ potassium cyanate $(282 \mathrm{mg}, 3.48$ mmol, 3 equiv) and deionized water ( $84 \mu \mathrm{L}, 4.64 \mathrm{mmol}$, 4 equiv) were ball-milled in a $12 \mathrm{~mL}$ stainless steel milling jar with 25 stainless steel milling balls ( $5 \mathrm{~mm}$ diameter). The mixture was ground at $450 \mathrm{rpm}$ for 6 cycles of milling of $10 \mathrm{~min}$, with a $5 \mathrm{~min}$ pause in between each cycle, with reverse rotation. Step $2: \mathrm{K}_{2} \mathrm{CO}_{3}(160 \mathrm{mg}, 1.16 \mathrm{mmol}, 1$ equiv) was added to the jar, and the mixture was ground again for a series of 6 cycles of milling of $10 \mathrm{~min}$, with a $5 \mathrm{~min}$ pause in between each cycle, with reverse rotation. $10 \%$ aqueous citric acid is then added to the crude until $\mathrm{pH}=5$, and the aqueous layer was extracted with ethyl acetate $(3 \times 5 \mathrm{~mL})$. The organic layer was dried over $\mathrm{MgSO} 4$, filtered, concentrated and dried over $\mathrm{P}_{2} \mathrm{O}_{5}$, affording the title compound as a white solid ( $173.9 \mathrm{mg}, 80 \%$ yield, e.r. $90: 10$ in favor of the $\mathrm{L}$-isomer); ${ }^{1} \mathrm{H}$ NMR (300 MHz, DMSO-d 6 ) $\delta(\mathrm{ppm}) 2.92(\mathrm{~d}, 2 \mathrm{H}, J=5.1 \mathrm{~Hz})$, $4.33(\mathrm{t}, 1 \mathrm{H}, J=6.1 \mathrm{~Hz}), 7.16-7.28(\mathrm{~m}, 5 \mathrm{H}), 7.94(\mathrm{~s}, 1 \mathrm{H}), 10.44(\mathrm{~s}$, $1 \mathrm{H}) ;{ }^{6}{ }^{13} \mathrm{C}\left\{{ }^{1} \mathrm{H}\right\}$ NMR (300 MHz, DMSO-d $d_{6} \delta(\mathrm{ppm}) 36.4,58.4$, 126.7, 128.1, 129.3, 129.8, 135.6, 157.1; ESI- $(+) \mathrm{m} / z 191[\mathrm{M}+\mathrm{H}]^{+}$.

Typical Procedure for the Synthesis of Compounds 3-21 (Table 3, entries 3-12 and 14-21). Step 1: amino methyl ester hydrochloride ( $250 \mathrm{mg}, 1$ equiv), potassium cyanate (3 equiv) and deionized water (4 equiv) were added to a $12 \mathrm{~mL}$ stainless steel milling jar with 25 stainless steel milling balls ( $5 \mathrm{~mm}$ diameter). The mixture was ground at $450 \mathrm{rpm}$ for 8 cycles of milling of $10 \mathrm{~min}$, with a 5 min pause in between each cycle, with reverse rotation. Step 2: the base $\left(\mathrm{K}_{2} \mathrm{CO}_{3}, \mathrm{Cs}_{2} \mathrm{CO}_{3}\right.$, triethylamine or a mixture of them, as reported in Table 3) was added to the jar, and the mixture was ground again at $450 \mathrm{rpm}$ for 8 cycles of milling of $10 \mathrm{~min}$, with a $5 \mathrm{~min}$ pause in between each cycle, with reverse rotation. Workup: $\mathrm{NH}_{4} \mathrm{Cl}$ (10 equiv) were added to the crude with ethyl acetate $(2 \mathrm{~mL})$, and the medium was ground at $450 \mathrm{rpm}$ for 3 cycles of $10 \mathrm{~min}$, with a $5 \mathrm{~min}$ pause in between each cycle, with reverse rotation. The precipitate, the organic layer, and the milling balls were transferred into a round-bottom flask containing AcOEt $(50 \mathrm{~mL})$ and left under stirring until no solid left on the balls. The organic layer was filtered and concentrated to afford the products as white solids.

(5R)-(Phenylmethyl)-2,4-imidazolidinedione 3 (Table 3, entry 3). CAS [3530-82-3]: (154.3 mg, 70\% yield, e.r. 90:10 in favor of the D-isomer); Step 2: The cyclization was performed using $\mathrm{K}_{2} \mathrm{CO}_{3}$ (160 mg, $1.16 \mathrm{mmol}, 1$ equiv) and $\mathrm{Et}_{3} \mathrm{~N}(162 \mu \mathrm{L}, 1.16 \mathrm{mmol}, 1$ equiv); ${ }^{1} \mathrm{H}$ NMR (300 MHz, DMSO- $\left.d_{6}\right) \delta(\mathrm{ppm}) 2.91-2.94(\mathrm{~m}, 2 \mathrm{H})$, $4.33(\mathrm{t}, 1 \mathrm{H}, J=4.1 \mathrm{~Hz}), 7.17-7.31(\mathrm{~m}, 5 \mathrm{H}), 7.91(\mathrm{~s}, 1 \mathrm{H}), 10.40(\mathrm{~s}$, $1 \mathrm{H}) ;{ }^{6}{ }^{13} \mathrm{C}\left\{{ }^{1} \mathrm{H}\right\}$ NMR $\left(300 \mathrm{MHz}, \mathrm{DMSO}-d_{6}\right) \delta(\mathrm{ppm}) 36.4,58.2$, 126.7, 128.1, 129.7, 135.6, 157.0, 175.1; ESI-(+) $\mathrm{m} / z 191[\mathrm{M}+\mathrm{H}]^{+}$. 5-p-(tert-Butyloxyphenyl)methyl-2,4-imidazolidinedione 4 (Table 3, entry 4). (227.6 mg, quant.). Step 2: The cyclization was performed using $\mathrm{Cs}_{2} \mathrm{CO}_{3}\left(849 \mathrm{mg}, 2.61 \mathrm{mmol}, 3\right.$ equiv). ${ }^{1} \mathrm{H}$ NMR $\left(300 \mathrm{MHz}, \mathrm{DMSO}-d_{6}\right) \delta(\mathrm{ppm}) 1.26(\mathrm{~s}, 9 \mathrm{H}), 2.88(\mathrm{~m}, 2 \mathrm{H}), 4.28(\mathrm{t}$, $1 \mathrm{H}, J=5.1 \mathrm{~Hz}), 6.85(\mathrm{~d}, 2 \mathrm{H}, J=8.5 \mathrm{~Hz}), 7.09(\mathrm{~d}, 2 \mathrm{H}, J=8.5 \mathrm{~Hz})$, 7.89 (s, 1H), $10.43(\mathrm{~s}, 1 \mathrm{H}) ;{ }^{13} \mathrm{C}\left\{{ }^{1} \mathrm{H}\right\}$ NMR (300 MHz, DMSO-d $\left.d_{6}\right) \delta$ (ppm) 38.6, 35.8, 58.5, 77.7, 123.3, 130.19, 130.23, 153.8, 157.2, 
175.3; ESI-(+) $m / z 263[\mathrm{M}+\mathrm{H}]^{+}, 248,207$; HRMS ESI-(+) calcd. for $\mathrm{C}_{14} \mathrm{H}_{18} \mathrm{~N}_{2} \mathrm{O}_{3}[\mathrm{M}+\mathrm{H}]^{+}$263.1396, found 263.1394.

5-[2-(Methylthio)ethyl]-2,4-imidazolidinedione 5 (Table 3, entry 5). CAS [13253-44-6]. (198.2 mg, 91\% yield). Step 2: The cyclization was performed using $\mathrm{K}_{2} \mathrm{CO}_{3}(173 \mathrm{mg}, 1.25 \mathrm{mmol}, 1$ equiv). ${ }^{1} \mathrm{H}$ NMR (300 MHz, DMSO- $\left.d_{6}\right) \delta(\mathrm{ppm}) 1.69-1.81(\mathrm{~m}, 1 \mathrm{H}), 1.86-$ $1.97(\mathrm{~m}, 1 \mathrm{H}), 2.53(\mathrm{~m}, 2 \mathrm{H}), 4.08(\mathrm{qd}, 1 \mathrm{H}, J=1.1 \mathrm{~Hz}, J=4.5 \mathrm{~Hz}), 7.99$ $(\mathrm{s}, 1 \mathrm{H}), 10.63(\mathrm{~s}, 1 \mathrm{H}) ;{ }^{82}{ }^{13} \mathrm{C}\left\{{ }^{1} \mathrm{H}\right\}$ NMR $\left(300 \mathrm{MHz}, \mathrm{DMSO}-d_{6}\right) \delta$ (ppm) 14.9, 29.3, 31.5, 56.9, 157.8, 176.3; ESI- $(+) m / z 175[\mathrm{M}+\mathrm{H}]^{+}$, 147, 103.

3-Methyl-5-[[(phenylmethyl)thio]methyl]-2,4-imidazolidinedione 6 (Table 3, entry 6). CAS [20210-01-9]. (186.9 mg, 84\% yield). Step 2: The cyclization was performed using $\mathrm{Cs}_{2} \mathrm{CO}_{3}(938 \mathrm{mg}$, $2.88 \mathrm{mmol}, 3$ equiv). ${ }^{1} \mathrm{H}$ NMR $\left(300 \mathrm{MHz}, \mathrm{DMSO}-d_{6}\right) \delta(\mathrm{ppm}) 2.72$ $(\mathrm{m}, 2 \mathrm{H}), 3.78(\mathrm{~s}, 2 \mathrm{H}), 4.32(\mathrm{t}, 1 \mathrm{H}, J=3.8 \mathrm{~Hz}), 7.27(\mathrm{~m}, 5 \mathrm{H}), 8.01(\mathrm{~s}$, $1 \mathrm{H}), 10.74(\mathrm{~s}, 1 \mathrm{H}) ;{ }^{13} \mathrm{C}\left\{{ }^{1} \mathrm{H}\right\}$ NMR $\left(300 \mathrm{MHz}, \mathrm{DMSO}-d_{6}\right) \delta(\mathrm{ppm})$ 32.0, 35.9, 57.7, 126.9, 128.4, 128.9, 138.3, 157.6, 174.8; ${ }^{83}$ ESI- $(+) \mathrm{m} / \mathrm{z}$ $237[\mathrm{M}+\mathrm{H}]^{+}$.

5-Methyl-2,4-imidazolidinedione 7 (Table 3, entry 7). CAS [616-03-5]. ( $165.0 \mathrm{mg}, 81 \%$ yield). Step 2: The cyclization was performed using $\mathrm{Cs}_{2} \mathrm{CO}_{3}$ (1.75 g, $5.37 \mathrm{mmol}, 3$ equiv). ${ }^{1} \mathrm{H}$ NMR (300 $\left.\mathrm{MHz}, \mathrm{DMSO}-d_{6}\right) \delta(\mathrm{ppm}) 1.21(\mathrm{~d}, 3 \mathrm{H}, J=6.9 \mathrm{~Hz}), 4.02(\mathrm{qd}, 1 \mathrm{H}, J=$ $6.9 \mathrm{~Hz}), 7.87(\mathrm{~s}, 1 \mathrm{H}), 10.57(\mathrm{~s}, 1 \mathrm{H}) ;{ }^{13} \mathrm{C}\left\{{ }^{1} \mathrm{H}\right\}$ NMR $(300 \mathrm{MHz}$, DMSO- $\left.d_{6}\right) \delta(\mathrm{ppm}) 17.5,55.0,157.8,177.1 ;^{74}$ ESI- $(+) \mathrm{m} / z 115[\mathrm{M}+$ $\mathrm{H}]^{+}, 133\left[\mathrm{M}+\mathrm{H}_{2} \mathrm{O}\right]^{+}$

5-Isopropyl-2,4-imidazolidinedione 8 (Table 3, entry $\mathbf{8}$ ). CAS [16935-34-5]. (200.1 mg, 94\% yield). Step 2: The cyclization was performed using $\mathrm{Cs}_{2} \mathrm{CO}_{3}$ (1.46 g, $4.47 \mathrm{mmol}, 3$ equiv). ${ }^{1} \mathrm{H}$ NMR (300 MHz, DMSO- $\left.d_{6}\right) \delta(\mathrm{ppm}) 0.79(\mathrm{~d}, 3 \mathrm{H}, J=6.8 \mathrm{~Hz}), 0.93(\mathrm{~d}, 3 \mathrm{H}, J=$ $6.9 \mathrm{~Hz}), 1.98(\mathrm{~m}, 2 \mathrm{H}), 3.90(\mathrm{dd}, 1 \mathrm{H}, J=1.3 \mathrm{~Hz}, J=3.5 \mathrm{~Hz}), 7.91(\mathrm{~s}$, $1 \mathrm{H}), 10.57(\mathrm{~s}, 1 \mathrm{H}) ;{ }^{6}{ }^{13} \mathrm{C}\left\{{ }^{1} \mathrm{H}\right\}$ NMR (300 MHz, DMSO-d $\left.d_{6}\right) \delta(\mathrm{ppm})$ 15.8, 18.6, 29.5, 62.1, 157.8, 175.4; ESI-(+) $m / z 143[\mathrm{M}+\mathrm{H}]^{+}, 161$ $\left[\mathrm{M}+\mathrm{H}_{2} \mathrm{O}\right]^{+}$.

5-(1-Methylpropyl)-2,4-imidazolidinedione 9 (Table 3, entry 9). CAS [62540-98-1]. (183.6 mg, 85\% yield). Step 2: The cyclization was performed using $\mathrm{Cs}_{2} \mathrm{CO}_{3}(1.35 \mathrm{~g}, 4.13 \mathrm{mmol}, 3$ equiv). ${ }^{1} \mathrm{H}$ NMR (300 MHz, DMSO- $\left.d_{6}\right) \delta(\mathrm{ppm}) 0.82-0.91(\mathrm{~m}, 6 \mathrm{H})$, $1.16-1.22(\mathrm{~m}, 1 \mathrm{H}), 1.28-1.33(\mathrm{~m}, 1 \mathrm{H}), 3.94(\mathrm{dd}, 1 \mathrm{H}, J=1.1 \mathrm{~Hz}, J=$ $3.5 \mathrm{~Hz}), 7.90(\mathrm{~s}, 1 \mathrm{H}), 10.57(\mathrm{~s}, 1 \mathrm{H}) ;{ }^{6}{ }^{13} \mathrm{C}\left\{{ }^{1} \mathrm{H}\right\}$ NMR $(300 \mathrm{MHz}$, DMSO- $\left.d_{6}\right) \delta(\mathrm{ppm}) 11.6,15.0,23.3,36.3,62.2,157.7,175.4$; ESI-(+) $m / z 157[\mathrm{M}+\mathrm{H}]^{+}$.

5-(2-Methylpropyl)-2,4-imidazolidinedione 10 (Table 3, entry 10). CAS [67337-73-9]. (200.0 mg, 93\% yield). Step 2: The cyclization was performed using $\mathrm{Cs}_{2} \mathrm{CO}_{3}(1.35 \mathrm{~g}, 4.13 \mathrm{mmol}, 3$ equiv). ${ }^{1} \mathrm{H}$ NMR $\left(300 \mathrm{MHz}, \mathrm{DMSO}-d_{6}\right) \delta(\mathrm{ppm}) 0.85-0.89(\mathrm{~m}, 6 \mathrm{H})$, $1.37-1.48(\mathrm{~m}, 2 \mathrm{H}), 1.70-1.77(\mathrm{~m}, 1 \mathrm{H}), 3.97-4.02(\mathrm{~m}, 1 \mathrm{H}), 8.00(\mathrm{~s}$, $1 \mathrm{H}) ;{ }^{6} \mathrm{C}\left\{{ }^{1} \mathrm{H}\right\}$ NMR (300 MHz, DMSO- $\left.d_{6}\right) \delta$ (ppm) 21.4, 23.1, 24.1, 41.3, 56.1, 157.4, 176.5; ESI- $(+) \mathrm{m} / z 157[\mathrm{M}+\mathrm{H}]^{+}$.

5-tert-Butoxymethyl-2,4-imidazolidinedione 11 (Table 3, entry 11). (218.8 mg, quant.). Step 2: The cyclization was performed using $\mathrm{Cs}_{2} \mathrm{CO}_{3}\left(1.15 \mathrm{~g}, 3.54 \mathrm{mmol}, 3\right.$ equiv). ${ }^{1} \mathrm{H}$ NMR $(300 \mathrm{MHz}$, DMSO-d $\left.d_{6}\right) \delta(\mathrm{ppm}) 1.10(\mathrm{~s}, 9 \mathrm{H}), 3.49(\mathrm{~m}, 2 \mathrm{H}), 4.07$ (pseudo-s, $\left.1 \mathrm{H}\right)$, $7.80(\mathrm{~s}, 1 \mathrm{H}), 10.49(\mathrm{~s}, 1 \mathrm{H}) ;{ }^{13} \mathrm{C}\left\{{ }^{1} \mathrm{H}\right\}$ NMR (300 MHz, DMSO-d $\left.d_{6}\right) \delta$ (ppm) 27.2, 58.7, 60.5, 72.8, 157.8, 174.3; ESI-(+) $m / z 187[\mathrm{M}+\mathrm{H}]^{+}$, $205\left[\mathrm{M}+\mathrm{H}_{2} \mathrm{O}\right]^{+}$; HRMS ESI- $(+)$calcd. for $\mathrm{C}_{8} \mathrm{H}_{14} \mathrm{~N}_{2} \mathrm{O}_{3}[\mathrm{M}+\mathrm{H}]^{+}$ 187.1083 , found 187.1083 .

5-(1-tert-Butoxyethyl)-2,4-imidazolidinedione 12 (Table 3, entry 12). ( $139.2 \mathrm{mg}, 96 \%$ yield). Step 2: The cyclization was performed using $\mathrm{Cs}_{2} \mathrm{CO}_{3}$ (715 mg, $2.20 \mathrm{mmol}, 3$ equiv). ${ }^{1} \mathrm{H}$ NMR $\left(300 \mathrm{MHz}, \mathrm{DMSO}-d_{6}\right) \delta(\mathrm{ppm}) 1.07(\mathrm{~s}, 9 \mathrm{H}), 1.15(\mathrm{~d}, 3 \mathrm{H}, J=6.3 \mathrm{~Hz})$, 3.83-3.92 (m, 1H), $7.87(\mathrm{~s}, 1 \mathrm{H}) ;{ }^{13} \mathrm{C}\left\{{ }^{1} \mathrm{H}\right\}$ NMR (300 MHz, DMSO$\left.d_{6}\right) \delta(\mathrm{ppm}) 20.4,28.4,63.9,65.8,73.1,157.9,174.5$; ESI- $(+) \mathrm{m} / z 201$ $[\mathrm{M}+\mathrm{H}]^{+}$, 145; HRMS ESI- $(+)$calcd. for $\mathrm{C}_{9} \mathrm{H}_{16} \mathrm{~N}_{2} \mathrm{O}_{3}[\mathrm{M}+\mathrm{H}]^{+}$ 201.1239, found 201.1232.

Methyl $\mathrm{N}$-(aminocarbonyl)-(tert-butyl)threoninate 13 (Table 3 , entry 13). The synthesis was performed as for compound 2 using Method B (247.7 mg, 96\% yield). ${ }^{1} \mathrm{H}$ NMR (300 MHz, DMSO- $\left.d_{6}\right) \delta$ (ppm) 1.07 (pseudo-s, 12H), $3.61(\mathrm{~s}, 3 \mathrm{H}), 4.08-4.18(\mathrm{~m}, 1 \mathrm{H}), 5.84$ $(\mathrm{s}, 2 \mathrm{H}), 5.98(\mathrm{~d}, 1 \mathrm{H}, J=9.4 \mathrm{~Hz}) ;{ }^{13} \mathrm{C}\left\{{ }^{1} \mathrm{H}\right\}$ NMR $(300 \mathrm{MHz}$, DMSO$\left.d_{6}\right) \delta(\mathrm{ppm}) 20.5,28.1,51.5,57.9,67.3,73.3,158.6,172.1$; ESI- $(+) \mathrm{m} /$ $z 233[\mathrm{M}+\mathrm{H}]^{+}, 255[\mathrm{M}+\mathrm{Na}]^{+}, 177,134$; HRMS ESI- $(+)$ calcd. for $\mathrm{C}_{10} \mathrm{H}_{20} \mathrm{~N}_{2} \mathrm{O}_{4}[\mathrm{M}+\mathrm{H}]^{+}$233.1501, found 233.1501.

5-Phenyl-2,4-imidazolidinedione 14 (Table 3, entry 14). CAS [89-24-7]. (210.8 mg, 97\% yield). Step 2: The cyclization was performed using $\mathrm{Cs}_{2} \mathrm{CO}_{3}\left(1.20 \mathrm{~g}, 3.69 \mathrm{mmol}, 3\right.$ equiv) and $\mathrm{Et}_{3} \mathrm{~N}$ (171 $\mu \mathrm{L}, 1.23 \mathrm{mmol}, 1$ equiv). Workup: Treatment with $\mathrm{NH} 4 \mathrm{Cl}$ followed by washing with $10 \%$ aq. citric acid and drying over $\mathrm{P}_{2} \mathrm{O}_{5} .{ }^{1} \mathrm{H}$ NMR (300 $\left.\mathrm{MHz}, \mathrm{DMSO}-d_{6}\right) \delta(\mathrm{ppm}) 5.16(\mathrm{~s}, 1 \mathrm{H}), 7.32-7.41(\mathrm{~m}, 5 \mathrm{H}), 8.39(\mathrm{~s}$, $1 \mathrm{H}), 10.78(\mathrm{~s}, 1 \mathrm{H}) ;{ }^{6}{ }^{13} \mathrm{C}\left\{{ }^{1} \mathrm{H}\right\}$ NMR $\left(300 \mathrm{MHz}, \mathrm{DMSO}-d_{6}\right) \delta(\mathrm{ppm})$ $61.2,126.7,128.2,128.7,136.1,157.5,174.2$; ESI- $(+) m / z 177[\mathrm{M}+$ $\mathrm{H}]^{+}$.

2,5-Dioxo-4-Imidazolidine acetic acid methyl ester 15 (Table 3, entry 15). CAS [78212-20-1]. (70.6 mg, 32\% yield). Step 2: The cyclization was performed using $\mathrm{Cs}_{2} \mathrm{CO}_{3}(1.24 \mathrm{~g}, 3.80$ mmol, 3 equiv). ${ }^{1} \mathrm{H}$ NMR (300 MHz, DMSO- $\left.d_{6}\right) \delta(\mathrm{ppm}) 2.71(\mathrm{~d}$, $2 \mathrm{H}, J=5.4 \mathrm{~Hz}), 4.25(\mathrm{t}, 1 \mathrm{H}, J=5.5 \mathrm{~Hz}), 7.89(\mathrm{~s}, 1 \mathrm{H}), 10.67(\mathrm{~s}, 1 \mathrm{H})$; ${ }^{13} \mathrm{C}\left\{{ }^{1} \mathrm{H}\right\}$ NMR (300 MHz, DMSO- $\left.d_{6}\right) \delta(\mathrm{ppm}) 35.3,51.7,54.2,157.6$, 159.6, 169.9, 175.1; ${ }^{74}$ ESI-(+) $m / z 173[\mathrm{M}+\mathrm{H}]^{+}, 159,141,103$.

Benzyl 4-(2,5-dioxoimidazolidin-4-yl)-butylcarbamate 16 (Table 3, entry 16). CAS [67320-75-6]. (212.7 mg, 91\% yield). Step 2: The cyclization was performed using $\mathrm{Cs}_{2} \mathrm{CO}_{3}(740 \mathrm{mg}, 2.27$ mmol, 3 equiv). ${ }^{1} \mathrm{H}$ NMR (300 MHz, DMSO- $\left.d_{6}\right) \delta$ (ppm) $1.08-1.71$ $(\mathrm{m}, 6 \mathrm{H}), 2.98(\mathrm{q}, 2 \mathrm{H}, J=6.3 \mathrm{~Hz}), 3.98(\mathrm{t}, 1 \mathrm{H}, J=4.9 \mathrm{~Hz}), 5.04(\mathrm{~s}$, 2H), 7.22-7.41 (m, 5H), $7.93(\mathrm{~s}, 1 \mathrm{H}), 10.59(\mathrm{~s}, 1 \mathrm{H}) ;{ }^{13} \mathrm{C}\left\{{ }^{1} \mathrm{H}\right\} \mathrm{NMR}$ $\left(300 \mathrm{MHz}, \mathrm{DMSO}-d_{6}\right) \delta$ (ppm) 21.5, 29.0, 30.9, 57.5, 65.1, 74.3, 127.7, 128.3, 137.3, 156.1, 157.5, 176.1; ESI- $(+) m / z 306[\mathrm{M}+\mathrm{H}]^{+}$, $328[\mathrm{M}+\mathrm{Na}]^{+}, 262$; HRMS ESI-(+) calcd. for $\mathrm{C}_{15} \mathrm{H}_{19} \mathrm{~N}_{3} \mathrm{O}_{4}[\mathrm{M}+\mathrm{H}]^{+}$ 306.1454 , found 306.1451

Tetrahydro- $1 \mathrm{H}$-Pyrrolo(1,2-c)-imidazole-1,3(2H)-dione 17 (Table 3, entry 17). CAS [5768-79-6]. (191.7 mg, 91\%). Step 2: The cyclization was performed using $\mathrm{K}_{2} \mathrm{CO}_{3}(492 \mathrm{mg}, 1.51 \mathrm{mmol}, 1$ equiv) and $\mathrm{Et}_{3} \mathrm{~N}\left(211 \mu \mathrm{L}, 1.51 \mathrm{mmol}, 1\right.$ equiv). ${ }^{1} \mathrm{H} \mathrm{NMR}(300 \mathrm{MHz}$, DMSO- $\left.d_{6}\right) \delta(\mathrm{ppm}) 1.58-1.71(\mathrm{~m}, 1 \mathrm{H}), 1.91-2.08(\mathrm{~m}, 3 \mathrm{H}), 2.97-$ $3.08(\mathrm{~m}, 1 \mathrm{H}), 3.42-3.50(\mathrm{~m}, 1 \mathrm{H}), 4.08-4.14(\mathrm{~m}, 1 \mathrm{H}), 10.74(\mathrm{~s}, 1 \mathrm{H})$; ${ }^{13} \mathrm{C}\left\{{ }^{1} \mathrm{H}\right\}$ NMR (300 MHz, DMSO- $\left.d_{6}\right) \delta$ (ppm) 26.6, 26.7, 44.9, 63.9, $160.9,175.4{ }^{21}$ ESI- $(+) m / z 141[\mathrm{M}+\mathrm{H}]^{+}$.

5-(1H-Indol-3-ylmethyl)-2,4-imidazolidinedione 18 (Table 3, entry 18). CAS [21753-16-2]. (131.2 mg, 77\% yield). Step 2: The cyclization was performed upon urea derivative $(193 \mathrm{mg}, 0.44 \mathrm{mmol})$ using $\mathrm{Cs}_{2} \mathrm{CO}_{3}\left(426 \mathrm{mg}, 1.30 \mathrm{mmol}, 3\right.$ equiv) and $\mathrm{Et}_{3} \mathrm{~N}(61 \mu \mathrm{L}, 0.44$ mmol, 1 equiv). Workup: Treatment with $\mathrm{NH}_{4} \mathrm{Cl}$ followed by washing with $10 \%$ aq. citric acid and drying over $\mathrm{P}_{2} \mathrm{O}_{5} .{ }^{1} \mathrm{H}$ NMR $(300 \mathrm{MHz}$, DMSO- $\left.d_{6}\right) \delta(\mathrm{ppm}) 3.06(\mathrm{~d}, 2 \mathrm{H}, J=4.8 \mathrm{~Hz}), 4.30(\mathrm{t}, 1 \mathrm{H}, J=4.0 \mathrm{~Hz})$, $6.94(\mathrm{t}, 1 \mathrm{H}, J=6.9 \mathrm{~Hz}), 6.99(\mathrm{t}, 1 \mathrm{H}, J=7.0 \mathrm{~Hz}), 7.12(\mathrm{~d}, 1 \mathrm{H}, J=2.3$ $\mathrm{Hz}), 7.31(\mathrm{~d}, 1 \mathrm{H}, J=7.9 \mathrm{~Hz}), 7.54(\mathrm{~d}, 1 \mathrm{H}, J=7.8 \mathrm{~Hz}), 7.88(\mathrm{~s}, 1 \mathrm{H})$, $10.35(\mathrm{~s}, 1 \mathrm{H}), 10.89(\mathrm{~s}, 1 \mathrm{H}) ;{ }^{13} \mathrm{C}\left\{{ }^{1} \mathrm{H}\right\}$ NMR $\left(300 \mathrm{MHz}, \mathrm{DMSO}-d_{6}\right) \delta$ (ppm) 26.5, 58.3, 107.9, 111.2, 118.3, 118.6, 120.8, 124.1, 127.5, 135.9, 157.4, 175.8; ESI-(+) $m / z 230[\mathrm{M}+\mathrm{H}]^{+}, 130$.

Methyl 2-amino-2-methylpropanoate hydrochloride. CAS [15028-41-8]. To a suspension of 2-aminoisobutyric acid (2.34 g, $22.70 \mathrm{mmol})$ in anhydrous methanol $(15 \mathrm{~mL})$ was slowly added trimethylsilyl chloride $(12.70 \mathrm{~mL}, 100.00 \mathrm{mmol}, 4.4$ equiv $)$ at $0{ }^{\circ} \mathrm{C}$ under $\mathrm{N}_{2}$. The mixture was left under stirring for $48 \mathrm{~h}$ at room temperature. The solvent was then evaporated, and the white solid was recrystallized in diethyl ether. The white crystals were dried over $\mathrm{P}_{2} \mathrm{O}_{5}$. (3.38 g, 97\% yield); ${ }^{1} \mathrm{H}$ NMR (300 MHz, DMSO- $\left.d_{6}\right) \delta(\mathrm{ppm}) 1.48(\mathrm{~s}$, $6 \mathrm{H}), 3.73(\mathrm{~s}, 3 \mathrm{H}), 8.80$ (broad s, $3 \mathrm{H}) ;{ }^{13} \mathrm{C}\left\{{ }^{1} \mathrm{H}\right\} \mathrm{NMR}(300 \mathrm{MHz}$, DMSO- $\left.d_{6}\right) \delta(\mathrm{ppm}) 23.2,53.1,55.7,171.9 ;{ }^{84}$ ESI-(+) $m / z 118[\mathrm{M}+$ $\mathrm{H}]^{+}$.

5,5'-Dimethyl-2,4-imidazolidinedione 19 (Table 3, entry 19). CAS [77-71-4]. (192.2 mg, 92\% yield). Step 2: The cyclization was performed using $\mathrm{K}_{2} \mathrm{CO}_{3}\left(225 \mathrm{mg}, 1.63 \mathrm{mmol}, 1\right.$ equiv). ${ }^{1} \mathrm{H}$ NMR (300 MHz, DMSO-d $\left.d_{6}\right) \delta(\mathrm{ppm}) 1.24(\mathrm{~s}, 6 \mathrm{H}), 7.94(\mathrm{~s}, 1 \mathrm{H}), 10.54(\mathrm{~s}, 1 \mathrm{H})$; ${ }^{13} \mathrm{C}\left\{{ }^{1} \mathrm{H}\right\}$ NMR $\left(300 \mathrm{MHz}, \mathrm{DMSO}-d_{6}\right) \delta(\mathrm{ppm}) 24.6,58.8,155.9$, $179.1{ }^{85} \operatorname{ESI}-(+) m / z 129[\mathrm{M}+\mathrm{H}]^{+}$.

Dihydrouracil 20 (Table 3, entry 20). CAS [504-07-4]. (96.2 $\mathrm{mg}, 47 \%$ yield). Step 2: The cyclization was performed using $\mathrm{Cs}_{2} \mathrm{CO}_{3}$ $(1.75 \mathrm{~g}, 5.37 \mathrm{mmol}, 3$ equiv). Workup: Filtration of the salts on silica with pure ethyl acetate was performed to recover the product. ${ }^{1} \mathrm{H}$ NMR (300 MHz, DMSO- $\left.d_{6}\right) \delta(\mathrm{ppm}) 2.43(\mathrm{t}, 2 \mathrm{H}, J=6.8 \mathrm{~Hz}), 3.19$ 
$(\mathrm{td}, J=2.7 \mathrm{~Hz}, J=6.8 \mathrm{~Hz}), 7.47(\mathrm{~s}, 1 \mathrm{H}), 9.93(\mathrm{~s}, 1 \mathrm{H}) ;{ }^{13} \mathrm{C}\left\{{ }^{1} \mathrm{H}\right\} \mathrm{NMR}$ $\left(300 \mathrm{MHz}, \mathrm{DMSO}-d_{6}\right) \delta$ (ppm) $30.4,35.4,154.0,171.1{ }^{86}$ ESI- $(+) \mathrm{m} /$ $z 133[\mathrm{M}+\mathrm{H}]^{+}$.

Methyl 3-amino-2-methylpropanoate hydrochloride. To a suspension of 3-aminoisobutyric acid $(5.00 \mathrm{~g}, 56.12 \mathrm{mmol})$ in anhydrous methanol $(25 \mathrm{~mL})$ was slowly added trimethylsilyl chloride (35.61 mL, $280.62 \mathrm{mmol}$ ) at $0{ }^{\circ} \mathrm{C}$ under $\mathrm{N}_{2}$. The mixture was left under stirring for $48 \mathrm{~h}$ at room temperature. The solvent was then evaporated, and the white solid was recrystallized in diethyl ether. The white crystals were dried over $\mathrm{P}_{2} \mathrm{O}_{5} .(1.14 \mathrm{~g}$, $75 \%$ yield $)$; CAS [137132-12-8]. ${ }^{1} \mathrm{H}$ NMR (300 MHz, DMSO- $\left.d_{6}\right) \delta(\mathrm{ppm}) 1.16(\mathrm{~d}$, $3 \mathrm{H}, J=6.6 \mathrm{~Hz}), 2.86(\mathrm{~m}, 2 \mathrm{H}), 3.03(\mathrm{~m}, 1 \mathrm{H}), 3.64(\mathrm{~s}, 3 \mathrm{H}), 8.26($ broad s, $3 \mathrm{H}) ;{ }^{13} \mathrm{C}\left\{{ }^{1} \mathrm{H}\right\}$ NMR $\left(300 \mathrm{MHz}, \mathrm{DMSO}-d_{6}\right) \delta(\mathrm{ppm}) 14.7,40.7$, 52.0, 173.7; ESI- $(+) \mathrm{m} / z 118[\mathrm{M}+\mathrm{H}]^{+}$; HRMS ESI- $(+)$calcd. for $\mathrm{C}_{5} \mathrm{H}_{11} \mathrm{NO}_{2}[\mathrm{M}+\mathrm{H}]^{+}$118.0868, found 118.0868.

Dihydrothymine 21 (Table 3, entry 21). CAS [696-04-8]; (118.9 mg, 57\% yield); Step 2: The cyclization was performed using $\mathrm{Cs}_{2} \mathrm{CO}_{3}$ (1.59 g, $4.88 \mathrm{mmol}, 3$ equiv). Workup: Same as compound 20. ${ }^{1} \mathrm{H}$ NMR (300 MHz, DMSO- $\left.d_{6}\right) \delta(\mathrm{ppm}) 1.04(\mathrm{~d}, 3 \mathrm{H}, J=7.0 \mathrm{~Hz})$, $2.52-2.59(\mathrm{~m}, 1 \mathrm{H}), 2.93(\mathrm{t}, 1 \mathrm{H}, J=11.0 \mathrm{~Hz}), 3.20-3.27(\mathrm{~m}, 1 \mathrm{H})$, $7.48(\mathrm{~s}, 1 \mathrm{H}), 9.89(\mathrm{~s}, 1 \mathrm{H}) ;{ }^{13} \mathrm{C}\left\{{ }^{1} \mathrm{H}\right\}$ NMR (300 MHz, DMSO- $\left.d_{6}\right) \delta$ (ppm) 12.6, 34.5, 42.2, 154.2, 174.0; ESI-(+) $\mathrm{m} / z 129[\mathrm{M}+\mathrm{H}]^{+}$.

Methyl 2-amino-2,2-phenylacetate. To a suspension of $\alpha, \alpha$ diphenylglycine $(2.00 \mathrm{~g}, 8.80 \mathrm{mmol})$ in methanol $(25 \mathrm{~mL})$ was added thionyl chloride $(0.64 \mathrm{~mL}, 8.80 \mathrm{mmol})$ at $0{ }^{\circ} \mathrm{C}$, and the mixture was left under stirring overnight at room temperature. Thionyl chloride $(2.56 \mathrm{~mL}, 36.20 \mathrm{mmol})$ was added slowly at $0{ }^{\circ} \mathrm{C}$, and the reaction medium was refluxed for $8 \mathrm{~h}$ and then left under stirring overnight at room temperature. This operation was repeated twice again, adding 5 equiv of $\mathrm{SOCl}_{2}$ each time. The solvent was evaporated and an aqueous solution of $\mathrm{NaHCO}_{3} 5 \%$ aq. $(10 \mathrm{~mL})$ was added to the crude, followed by extraction with ethyl acetate $(3 \times 5 \mathrm{~mL})$. The organic layer was dried over $\mathrm{MgSO}_{4}$ and concentrated. The crude was solubilized in methanol $(25 \mathrm{~mL})$ and $\mathrm{HCl} 1 \mathrm{~N}(4.5 \mathrm{~mL})$ was added. The mixture was left under stirring for $1 \mathrm{~h}$. The solvent was then evaporated, and the white solid was recrystallized in diethyl ether and dried over $\mathrm{P}_{2} \mathrm{O}_{5}$. (1.06 g, 43\% yield). CAS [93504-24-6]; ${ }^{1} \mathrm{H}$ NMR (300 MHz, DMSO-d $d_{6} \delta(\mathrm{ppm}) 3.86(\mathrm{~s}, 3 \mathrm{H}), 7.31-7.49(\mathrm{~m}, 10 \mathrm{H}), 9.74$ (broad s, $3 \mathrm{H}) ;{ }^{13} \mathrm{C}\left\{{ }^{1} \mathrm{H}\right\}$ NMR (300 MHz, DMSO- $\left.d_{6}\right) \delta(\mathrm{ppm}) 54.1,68.4,127.8$, 128.7, 129.3, 136.8, 169.6; ESI- $(+) m / z 242[\mathrm{M}+\mathrm{H}]^{+}, 225,197,165$; HRMS ESI- $(+)$ calcd. for $\mathrm{C}_{15} \mathrm{H}_{15} \mathrm{NO}_{2}[\mathrm{M}+\mathrm{H}]^{+} 242.1181$, found 242.1181 .

5,5-Diphenyl-2,4-imidazolidinedione (or Phenytoin) 22 (Table 3, entry 22). Step 1. $\alpha, \alpha$-diphenylglycine methyl ester hydrochloride $(125 \mathrm{mg}, 0.45 \mathrm{mmol})$ trimethylsilyl isocyanate (488 $\mu \mathrm{L}, 3.60 \mathrm{mmol}, 8$ equiv) and deionized water $(81 \mu \mathrm{L}, 4.50 \mathrm{mmol}, 10$ equiv) were added in a $12 \mathrm{~mL}$ stainless steel milling jar with 25 stainless steel milling balls ( $5 \mathrm{~mm}$ diameter). The mixture was ground continuously at $450 \mathrm{rpm}$ for $3 \mathrm{~h}$. Trimethylsilyl isocyanate $(488 \mu \mathrm{L}$, $3.60 \mathrm{mmol}, 8$ equiv) and deionized water $(81 \mu \mathrm{L}, 4.50 \mathrm{mmol}, 10$ equiv) were added, and the mixture was ground again for $3 \mathrm{~h}$ at 450 $\mathrm{rpm}$. A last portion of trimethylsilyl isocyanate $(244 \mu \mathrm{L}, 1.80 \mathrm{mmol}, 4$ equiv) was added with no additional water, and the reaction mixture was ground at $450 \mathrm{rpm}$ for $2 \mathrm{~h}$. Step 2. $\mathrm{Cs}_{2} \mathrm{CO}_{3}(440 \mathrm{mg}, 1.35 \mathrm{mmol}, 3$ equiv) was added to the jar, and the mixture was ground for a series of 12 cycles of milling ( $10 \mathrm{~min}$ milling followed by $5 \mathrm{~min}$ pause in between each cycle, with reverse rotation). Workup. $\mathrm{NH}_{4} \mathrm{Cl}(481 \mathrm{mg}$, $9.0 \mathrm{~mol}, 20$ equiv) and ethyl acetate $(2 \mathrm{~mL})$ were added to the crude, and the mixture was ground at $450 \mathrm{rpm}$ for 3 cycles of $10 \mathrm{~min}$ followed by $5 \mathrm{~min}$ pause in between each cycle, with reverse rotation. The precipitate, the organic layer, and the milling balls were transferred into a round-bottom flask containing AcOEt $(50 \mathrm{~mL})$ and left under stirring until no solid was left on the balls. The organic layer was filtered and concentrated in vacuo to afford the product as a white solid (95.6 mg, 84\% yield); CAS [57-41-0]; ${ }^{1} \mathrm{H}$ NMR (300 MHz, DMSO- $\left.d_{6}\right) \delta(\mathrm{ppm}) 7.26-7.40(\mathrm{~m}, 10 \mathrm{H}), 9.31(\mathrm{~s}, 1 \mathrm{H}), 11.10(\mathrm{~s}, 1 \mathrm{H})$; ${ }^{13} \mathrm{C}\left\{{ }^{1} \mathrm{H}\right\}$ NMR (300 MHz, DMSO- $\left.d_{6}\right) \delta$ (ppm) 70.2, 126.6, 128.0, $128.5,139.9,155.9,174.6{ }^{87}$ ESI- $(+) m / z 253[\mathrm{M}+\mathrm{H}]^{+}, 225$.

\section{AUTHOR INFORMATION}

\section{Corresponding Author}

*E-mail: evelina.colacino@univ-montp2.fr. Tel. +33 (0)4 6714 42 85. Fax +33 (0)467 144866 .

\section{Notes}

The authors declare no competing financial interest.

\section{ACKNOWLEDGMENTS}

The authors are grateful to Mr. Julien Fullenwarth (Institut Charles Gerhardt, Montpellier) for the access to the Planetary Mill Pulverisette 7 Premium (Fritsch) for some experiments.

\section{REFERENCES}

(1) Meusel, M.; Gutschow, M. Org. Prep. Proced. Int. 2004, 36, 391443.

(2) Dhanawat, M.; Banerjee, A. G.; Shrivastava, S. K. Med. Chem. Res. 2011, 21, 2807-2822.

(3) Kutt, H.; Harden, C. L. Handb. Exp. Pharmacol. 1999, 138, 229265

(4) Grosse, L.; Paquet, S.; Caron, P.; Fazli, L.; Rennie, P. S.; Belanger, A.; Barbier, O. Cancer Res. 2013, 73, 6963-6971.

(5) Iqbal, Z.; Ali, S.; Iqbal, J.; Abbas, Q.; Qureshi, I. Z.; Hameed, S. Bioorg. Med. Chem. Lett. 2013, 23, 488-491.

(6) Marton, J.; Enisz, J.; Hosztafi, S.; Timar, T. J. Agric. Food Chem. 1993, 41, 148-152.

(7) Ware, E. Chem. Rev. 1950, 46, 403-470.

(8) Faghihi, K.; Zamani, K.; Mirsamie, A.; Reza Sangi, M. Eur. Polym. J. 2003, 39, 247-254.

(9) Sabounchei, S. J.; Shahriary, P.; Salehzadeh, S.; Gholiee, Y.; Khavasi, H. R. J. Mol. Struct. 2013, 1051, 15-22.

(10) Sabounchei, S. J.; Shahriary, P.; Gholiee, Y.; Salehzadeh, S.; Khavasi, H. R.; Chehregani, A. Inorg. Chim. Acta 2014, 409, 265-275.

(11) Chassaing, C.; Haudrechy, A.; Langlois, Y. Tetrahedron Lett. 1997, 38, 4415-4416.

(12) Hernández-Torres, G.; Tan, B.; Barbas, C. F. Org. Lett. 2012, 14, $1858-1861$.

(13) Abdollahi-Alibeik, M.; Zaghaghi, Z. Chem. Pap. 2008, 63, 97101.

(14) Khazaei, A.; Zolfigol, M. A.; Rostami, A. Synthesis 2004, 29592961.

(15) Tabata, M.; Moriyama, K.; Togo, H. Eur. J. Org. Chem. 2014, $3402-3410$.

(16) Lopez, A. C.; Trigo, G. G. Adv. Heterocycl. Chem. 1985, 38, 177-228.

(17) Bucherer, H. T.; Libe, V. A. J. Prakt. Chem. 1934, 141, 5-43.

(18) Bucherer, H. T.; Steiner, W. J. Prakt. Chem. 1934, 140, 291316.

(19) Montagne, C.; Shiers, J. J.; Shipman, M. Tetrahedron Lett. 2006, 47, 9207-9209.

(20) Safari, J.; Gandomi-Ravandi, S.; Javadian, L. Synth. Commun. 2013, 43, 3115-3120.

(21) Kumar, V.; Rana, H.; Sankolli, R.; Kaushik, M. P. Tetrahedron Lett. 2011, 52, 6148-6151.

(22) Safari, J.; Javadian, L. C. R. Chim. 2013, 16, 1165-1171.

(23) Thielemann, H. Z. Chem. 1978, 18, 174.

(24) Read, W. T. J. Am. Chem. Soc. 1922, 44, 1746-1755.

(25) Kavalek, J.; Machacek, V.; Svobodova, G.; Sterba, V. Collect. Czech. Chem. Commun. 1986, 51, 375-390.

(26) Blériot, Y.; Simone, M. I.; Wormald, M. R.; Dwek, R. a.; Watkin, D. J.; Fleet, G. W. J. Tetrahedron: Asymmetry 2006, 17, 2276-2286. 
(27) Reichard, G. A.; Stengone, C.; Paliwal, S.; Mergelsberg, I.; Majmundar, S.; Wang, C.; Tiberi, R.; Mcphail, A. T.; Piwinski, J. J.; Shih, N. Org. Lett. 2003, 5, 4249-4251.

(28) Glass, R. S.; Hug, G. L.; Schöneich, C.; Wilson, G. S.; Kuznetsova, L.; Lee, T.; Ammam, M.; Lorance, E.; Nauser, T.; Nichol, G. S.; Yamamoto, T. J. Am. Chem. Soc. 2009, 131, 13791-13805.

(29) Colacino, E.; Lamaty, F.; Martinez, J.; Parrot, I. Tetrahedron Lett. 2007, 48, 5317-5320.

(30) Biltz, H. Ber. Dtsch. Chem. Ges. 1908, 41, 1379-1393.

(31) Dunnavant, W. R. J. Am. Chem. Soc. 1956, 78, 2740-2743.

(32) Safari, J.; Moshtael Naimeh, A.; Ramezan Anousheh, I. Chin. J. Chem. 2010, 28, 255-258.

(33) Arani, N. M.; Safari, J. Ultrason. Sonochem. 2011, 18, 640-643.

(34) Muccioli, G. G.; Poupaert, J. H.; Wouters, J.; Norberg, B.; Poppitz, W.; Scriba, G. K. .; Lambert, D. M. Tetrahedron 2003, 59, 1301-1307.

(35) Safari, J.; Naeimi, H.; Ghanbari, M. M.; Sabzi Fini, O. Russ. J. Org. Chem. 2009, 45, 477-479.

(36) Ananth, V. S.; Kumar, P. N.; Reddy, R. S. P. Int. J. ChemTech Res. 2010, 2, 592-597.

(37) Gbaguidi, F. A.; Kpoviessi, S. S. D.; Kapanda, C. N.; Muccioli, G. G.; Lambert, D. M.; Accrombessi, G. C.; Moudachirou, M.; Poupaert, J. H. Afr. J. Pure Appl. Chem. 2011, 5, 168-175.

(38) Poupaert, J. H.; De Keyser, J. L.; Vandervorst, D.; Dumont, P. Bull. Soc. Chim. Belg. 1984, 93, 493-495.

(39) Hashmi, I. A.; Aslam, A.; Ali, S. K.; Ahmed, V.; Ali, F. I. Synth. Commun. 2010, 40, 2869-2874.

(40) Regulation (EC) No 1907/2006 of the European Parliament and of the Council of 18 December 2006 concerning the Registration, Evaluation, Authorisation and Restriction of Chemicals (REACH), establishing a European Chemicals Agency. http://ec.europa.eu/enter.

(41) Martins, M. a P.; Frizzo, C. P.; Moreira, D. N.; Buriol, L.; Machado, P. Chem. Rev. 2009, 109, 4140-4182.

(42) Rothenberg, G.; Downie, a P.; Raston, C. L.; Scott, J. L. J. Am. Chem. Soc. 2001, 123, 8701-8708.

(43) Kaupp, G. CrystEngComm 2009, 11, 388.

(44) Stolle, A.; Szuppa, T.; Leonhardt, S. E. S.; Ondruschka, B. Chem. Soc. Rev. 2011, 40, 2317-2329.

(45) James, S. L.; Adams, C. J.; Bolm, C.; Braga, D.; Collier, P.; Friščić, T.; Grepioni, F.; Harris, K. D. M.; Hyett, G.; Jones, W.; Krebs, A.; Mack, J.; Maini, L.; Orpen, a G.; Parkin, I. P.; Shearouse, W. C.; Steed, J. W.; Waddell, D. C. Chem. Soc. Rev. 2012, 41, 413-447.

(46) Chauhan, P.; Chimni, S. S. Beilstein J. Org. Chem. 2012, 8, 2132-2141.

(47) Wang, G.-W. Chem. Soc. Rev. 2013, 42, 7668-7700.

(48) Kaupp, G.; Naimi-jamal, M. R. Eur. J. Org. Chem. 2002, 13681373

(49) Declerck, V.; Nun, P.; Martinez, J.; Lamaty, F. Angew. Chem., Int. Ed. Engl. 2009, 48, 9318-9321.

(50) Baron, A.; Martinez, J.; Lamaty, F. Tetrahedron Lett. 2010, 51, 6246-6249.

(51) Métro, T.-X.; Bonnamour, J.; Reidon, T.; Sarpoulet, J.; Martinez, J.; Lamaty, F. Chem. Commun. 2012, 48, 11781-11783.

(52) Nun, P.; Pérez, V.; Calmès, M.; Martinez, J.; Lamaty, F. Chem.-Eur. J. 2012, 18, 3773-3779.

(53) Konnert, L.; Gauliard, A.; Lamaty, F.; Martinez, J.; Colacino, E. ACS Sustainable Chem. Eng. 2013, 1, 1186-1191.

(54) Bonnamour, J.; Métro, T.-X.; Martinez, J.; Lamaty, F. Green Chem. 2013, 15, 1116.

(55) Colacino, E.; Nun, P.; Colacino, F. M.; Martinez, J.; Lamaty, F. Tetrahedron 2008, 64, 5569-5576.

(56) Konnert, L.; Lamaty, F.; Martinez, J.; Colacino, E. J. Org. Chem. 2014, 79, 4008-4017.

(57) Kaupp, G.; Schmeyers, J.; Boy, J. Tetrahedron 2000, 56, 68996911.

(58) Ferguson, M.; Giri, N.; Huang, X.; Apperley, D.; James, S. L. Green Chem. 2014, 16, 1374-1382.

(59) Hernández, J. G.; Butler, I. S.; Friščić, T. Chem. Sci. 2014, 5, $3576-3582$.
(60) Tyagi, M.; Khurana, D.; Kartha, K. P. R. Carbohydr. Res. 2013, $379,55-59$

(61) Balema, V. P.; Wiench, J. W.; Pruski, M.; Pecharsky, V. K. J. Am. Chem. Soc. 2002, 124, 6244-6245.

(62) March, J. Advanced Organic Chemistry, 4th ed.; John Wiley \& Sons: New York, 1992; p 424.

(63) Bunnett, J. F.; Davis, G. T. J. Am. Chem. Soc. 1960, 82, 665-674.

(64) Bruice, T. C.; Donzely, A.; Huffmany, R. W.; Butler, A. R. J. Am. Chem. Soc. 1967, 89, 2106-2121.

(65) Dakin, H. D. J. Biol. Chem. 1909, 6, 235-243.

(66) Taillades, J.; Boiteau, L.; Beuzelin, I.; Lagrille, O.; Biron, J.-P.; Vayaboury, W.; Vandenabeele-Trambouze, O.; Giani, O.; Commeyras, A. J. Chem. Soc., Perkin Trans. 2 2001, 1247-1254.

(67) De Luca, L.; Porcheddu, A.; Giacomelli, G.; Murgia, I. Synlett 2010, 2439-2442.

(68) Harries, C. D.; Weiss, M. Justus Liebigs Ann. Chem. 1903, 327, $355-384$.

(69) Tsuruoka, R.; Nagamachi, T.; Murakami, Y.; Komatsu, M.; Minakata, S. J. Org. Chem. 2009, 74, 1691-1697.

(70) Štrukil, V.; Margetić, D.; Igrc, M. D.; Eckert-Maksić, M.; Friščić, T. Chem. Commun. 2012, 48, 9705-9707.

(71) Štrukil, V.; Igrc, M. D.; Fábián, L.; Eckert-Maksić, M.; Childs, S. L.; Reid, D. G.; Duer, M. J.; Halasz, I.; Mottillo, C.; Friščić, T. Green Chem. 2012, 14, 2462.

(72) Tan, D.; Štrukil, V.; Mottillo, C.; Friščić, T. Chem. Commun. 2014, 50, 5248-5250.

(73) Bowmaker, G. a. Chem. Commun. 2013, 49, 334-348.

(74) Agrawal, S. K.; Sathe, M.; Halve, A. K.; Kaushik, M. P. Tetrahedron Lett. 2012, 53, 5996-5999.

(75) Ooms, F.; Wouters, J.; Oscari, O.; Happaerts, T.; Bouchard, G.; Carrupt, P.-A.; Testa, B.; Lambert, D. M. J. Med. Chem. 2002, 45, $1748-1756$

(76) Rishipathak, D. D.; Pal, S. C.; Belsare, D. P. Asian J. Chem. 2007, 19, 5450-5458.

(77) O’Neill, M.; Hauer, B.; Schneider, N.; Turner, N. J. ACS Catal. 2011, 1, 1014-1016.

(78) Dumbris, S. M.; Díaz, D. J.; McElwee-White, L. J. Org. Chem. 2009, 74, 8862-8865.

(79) Waddell, D. C.; Clark, T. D.; Mack, J. Tetrahedron Lett. 2012, $53,4510-4513$.

(80) Lebedev, A. V.; Sheludyakov, V. D.; Lebedeva, A. B. Russ. J. Appl. Chem. 2014, 87, 793-795.

(81) Schramm, H. W. Sci. Pharm. 1991, 59, 115-122.

(82) Shibuya, C.; Ouchi, S. Agric. Biol. Chem. 1988, 52, 589-591.

(83) Fraile, J. M.; Lafuente, G.; Mayoral, J. a.; Pallarés, A. Tetrahedron 2011, 67, 8639-8647.

(84) Kolano, C.; Gomann, K.; Sander, W. Eur. J. Org. Chem. 2004, 4167-4176.

(85) Faghihi, K.; Zamani, K.; Mobinikhaledi, A. Turk. J. Chem. 2004, $28,345-350$.

(86) Saladino, R.; Crestini, C.; Neri, V.; Ciciriello, F.; Costanzo, G.; Di Mauro, E. ChemBioChem 2006, 7, 1707-1714.

(87) Mahmoodi, N. O.; Khodaee, Z. ARKIVOC 2007, 29-36. 